\title{
Organic matter isotopes reveal enhanced rainfall activity in Northwestern Mediterranean borderland during warm substages of the last $200 \mathrm{kyr}$
}

\author{
Pasquier Virgil ${ }^{1,{ }^{*}}$, Toucanne Samuel ${ }^{2}$, Sansjofre Pierre ${ }^{1}$, Dixit Yama ${ }^{2,3}$, Revillon Sidonie ${ }^{1,4}$, \\ Mokeddem Zohra ${ }^{1}$, Rabineau Marina ${ }^{5}$
}

\author{
${ }^{1}$ UMR 6538 Laboratoire Géosciences Océan, Institut Universitaire Européen de la Mer, Place Nicolas \\ Copernic, 29280, Plouzané, France \\ 2 IFREMER, Laboratoire Géodynamique et enregistrements Sédimentaires, BP70, 29280, Plouzané, \\ France \\ ${ }^{3}$ Earth Observatory Singapore, Nanyang Technological University, 639798, Singapore \\ ${ }^{4}$ SEDISOR, Institut Universitaire Européen de la Mer, Place Nicolas Copernic, 29280, Plouzané, \\ France \\ *Corresponding author : Virgil Pasquier, email addresses : virgil.pasquier@univ-brest.fr ; \\ virgil.pasquier@weizmann.ac.il
}

\begin{abstract}
:
In this study we use bulk sediment organic matter stable isotopes ( $\delta 13 \mathrm{Corg}$ and $\delta 15 \mathrm{~N}$ ) to examine the nature and timing of preserved organic matter in borehole PRGL1-4 from Northwestern Mediterranean Sea. This region is known as a transitional zone between the North Atlantic atmospheric circulation and the North African monsoon system. In the Gulf of Lion (SE France), increased inputs of organic matter from sediment-laden rivers occurred during warm substages of the last $200 \mathrm{kyr}$ (MIS 5e, 5c, and 5a; MIS $6 \mathrm{~d}$, and 6b). Increased terrestrial organic matter are inferred from organic carbon isotopic composition ( $\delta 13 \mathrm{Corg}$ ), and are interpreted as resulting from enhanced rainfall over the Rhone river catchment area. Such increase in terrestrial organic carbon induced enhancement of the primary productivity leading to the formation of local oxygen minimum zone as demonstrated by $\sim 3 \%$ values in $\delta 15 \mathrm{~N}$. Comparison with regional paleohydrological records from the northern Mediterranean borderlands reveals the regional character of these pluvial events. Taking advantage of the location of PRGL1-4 borehole, out of Mediterranean cyclogenesis area, we suggest that the pluvial events recorded during warm substages of the last $200 \mathrm{kyr}$ occurred in response to enhanced passage of North Atlantic atmospheric perturbation over the Gulf of Lion catchment area (especially over Rhone river watershed which represent $80 \%$ of the GoL catchment area), a scenario possibly similar to that encountered today during negative- NAO like conditions. At a regional scale, our data suggests that high rainfall events over the Gulf of Lion catchement area and the Rhone watershed occurred at the time of North African summer monsoon and the sapropel deposition in the Mediterranean basin, thus highlighting a close coupling between mid- (North Atlantic) and low-latitudes (monsoon) climate systems. Importantly, our geochemical evidence from the Gulf of Lion support an extra-Mediterranean source for the regional pluvial events described in many paleoclimatic records from the northern Mediterrean borderlands during warm substages of the last climate cycles. Consequently, we suggest that this region as a whole could provide, in addition to the river runoff from the North African sector, the
\end{abstract}


necessary conditions for the sapropel deposition.

\section{Highlights}

- We examine the nature/timing of preserved organic matter in PRGL1-4 from the Gulf of Lion, NW Med. GoL experienced increase terrestrial OM during warms periods of the last $200 \mathrm{kyr}$ (MIS 5 and MIS 6). Increased terrestrial OM led to local OMZ are infered from OM stable isotopes $\left(\delta^{13} \mathrm{C}_{\text {org }}\right.$ and $\delta^{15} \mathrm{~N}$ ). High runnof from Rhone river point for intense runoff of extra-Mediterranean (Atlantic) into the GoL. Extra-Mediterranean addition from the $\mathrm{N}$ Med may act as a possible forcing for sapropel deposition.

Keywords : Mediterranean, Rainfall, North Atlantic oscillation, Organic matter, North Mediterranean borderland, Sapropel 


\section{Introduction}

The Mediterranean Sea occupies a critical transitional location between polar and subtropical air-masses. As a result, the Mediterranean hydroclimate, is controlled by both Atlantic climatic processes (i.e. driving the wintertime Mediterranean storm track) and the latitudinal migration of the Inter-Tropical Convergence Zone (ITCZ) (e.g. Rohling et al., 2015 for a thorough review). An exhaustive understanding of these two climatic systems is therefore required to establish regional climatic models (Bosmans et al., 2015; Kutzbach et al., 2014), and by extension evaluate the modern hydrological Mediterranean system and its contributions to the ongoing climate change.

The Mediterranean Sea as a whole is sensitive to atmospheric circulation changes, however its Western and Eastern basins are affected by different atmospheric processes. In the Eastern basin, past variations in moisture, rainfall and river discharges to the Mediterranean Sea are generally attributed to enhanced summer monsoon activity over North Africa, when ITCZ reached its northern position (see Fig. 1 for ITCZ position; Revel et al., 2010; Rossignol-Strick, 1985; 1983; Rohling et al., 2002). This pattern reaches a maxima during precession minima (i.e. interglacials) when the insolation peak induces a strong landsea thermal gradient and intensify the monsoon circulation. It is believed that the high monsoonal freshwater discharge into the Mediterranean results in sapropel deposition in the deep Mediterranean. Sapropel are dark layers containing high amount of organic materials that deposited under stratified seawater conditions (Rohling et al., 2015 for a throrough review). Therefore, main Mediterranean paleo-hydrological changes and the sapropel deposition have long been attributed to low latitude phenomena (i.e. ITCZ shifts). However, recent understanding of the Northeastern Mediterranean paleo-hydrology variations have shown increased precipitation over the entire Eastern Mediterranean region during the sapropel deposition (Soreq cave speleothem; Bar-Matthews et al., 2003). This is supported by many records of increased rainfall with Mediterranean signature during the last insolation maxima centred around 8 ka (sapropel S1 deposition; Arz et al., 2003), and evidence of available water in Greece peat land during its MIS 5 equivalent and the sapropel S5 deposition ( 125 ka; Tzedakis, 2007). The evidence of pluvial periods in Northeastern borderland calls into question the northward extent of the influence of the African monsoon during insolation maxima. 
Evidences of enhanced hydrological activity during sapropel S1 deposition have also been reported in Northwestern Mediterranean basin, northward of the ITCZ influence (Tuenter et al., 2003) (Fig. 1). As an example, the isotopic composition of cave's speleothem from central Italy (Antro del Corchia; Zanchetta et al., 2007), and studies from marine (Ariztegui et al., 2000) and lacustrine sediments (Magny et al., 2013) support this idea (Fig. 1). These findings, taken together with that from the Eastern Mediterranean Sea and Greece during MIS 5e and the Early Holocene (Arz et al., 2003; Bar-Matthews et al., 2003; Tzedakis, 2007), suggest a basin-wide increase in rainfall over the whole of Mediterranean (Bard et al., 2002; Kallel et al., 1997, 2000) with a strong Northern borderland contribution (from Corsica to Turkey; Rohling and Hilgen, 1991; Toucanne et al., 2015). Although the Western Mediterranean basin hydrological changes are more dependent of the North Atlantic atmospheric circulation (Kandiano et al., 2014; López-Moreno et al., 2011; Trigo et al., 2002), previous authors proposed that the enhancement of the hydrological activity over the Mediterranean borderlands during periods of sapropel deposition may result from enhanced propagations of North Atlantic atmospheric perturbations into the Western Mediterranean Sea (Kutzbach et al., 2013; Bard et al., 2002; Kallel et al., 2000; 1997; Rohling and Hilgen, 1991; Toucanne et al., 2015). In such a case, the flow of Atlantic depression (i.e. Mediterranean storm track) favoured the cyclogenesis over the Western Mediterranean, especially over the Gulf of Genoa (Trigo et al., 2002). Addressing this issue requires acquisition of well-located, regionally representative, and possibly independently dated records of climatic variability. There are only a few high resolution long sedimentary archives that explore the link between the North Atlantic and the Mediterranean climate (Sánchez Goñi et al., 2002; Martrat et al., 2004; 2007 among others), and also the influence of mid-latitude climate on the Mediterranean hydrology at the time of precession minima (Toucanne et al., 2015). Here, we bridge this gap by investigating the processes involved in the export, and preservation of organic land-derived materials into the Gulf of Lion (GoL), South East France, over the last $200 \mathrm{kyr}$. The GoL is a climate-sensitive margin located westward of the westernmost active Mediterranean cyclogenesis area (i.e. Gulf of Genoa), ideally located on the way of North Atlantic depression into the Western Mediterranean Sea. The GoL is prone to recording high resolution climate changes (including sea-level) due to the combination of high sediment inputs and high subsidence rates favourable for sediment accumulation (Cortina et al., 2015; 
Rabineau et al., 2006; 2014; Sierro et al., 2009 among others). Using $\delta^{13} C_{\text {org }}, \delta^{15} N_{\text {tot, }}$ Total Organic Carbon (TOC) and Total Nitrogen (TN), we track the origin of the organic matter (i.e. terrestrial vs marine) and then track the paleohydrology of the Pyrennean-Languedocian and the Western Alps (drained by the Rhone river) catchment area contribution to the Western Mediterranean Sea. This study improves the understanding of past climate mechanisms in the Mediterranean Sea, and in particular gives insight into the processes leading to enhanced precipitation over the Northern Mediterranean borderlands during insolation maxima.

\section{Geological Setting, material and methods}

2.1. PRGL 1-4 drill-core: a high-resolution record for GoL shelf history.

Located in the Northwestern Mediterranean basin, the GoL is characterised by a wide continental shelf $(70 \mathrm{~km})$, that was sub-aerially exposed during Quaternary glacial periods (Jouet et al., 2006; Rabineau et al., 2006). The shelf morphology has been studied in detail over the last decade, which highlighted important morphological features providing indicators of paleo-connection between fluvial systems and submarine canyons (Mauffrey et al., 2015).

Spatial and temporal distribution of sediment in the studied area are mostly governed by eustatic changes. Seismic investigations and dated sediment cores allowed a detailed reconstruction of sedimentary accumulation since the Messinian (ca. 6 Myr; Leroux et al., 2017; Rabineau et al., 2006 among others), which is described as a superposition of $100 \mathrm{kyr}$ seismic sequences separated by major discontinuities formed in response to glacio-eustatic sea level changes. In the GoL, seaward migration of the shoreline close to our study site ( 90/100 mbsf; Rabineau et al., 2006) induced high to very high sedimentation rates during glacial times (averaging $\sim 1$ to $2 \mathrm{~m} \mathrm{ka}^{-1}$ )

The present study is based on borehole PRGL 1-4 (42.690N; 3.838E), a 300 m continuous sediment core drilled on the upper slope (298 m water depth) of the GoL, on the interfluve of the Bourcart and Herault canyons (Fig. 1). Borehole PRGL 1-4 was drilled within the framework of the European Union project PROMESS1 (http://www.pangaea.de/Projects/PROMESS1/). 


\subsection{Organic matter Carbon and Nitrogen isotopes and quantification}

Sedimentary organic matter (OM) in marine environment is typically composed of a mixture of in-situ marine and land exported materials. Autochthonous OM grains are derived from land erosion, plant detritus and old marine deposits which has been already degraded to various degrees. The Rhone river is the main sediment provider (>80\%) in the GoL, and with a drainage area of $97,8000 \mathrm{~km}^{2}$ constitutes the second largest river watershed of the Mediterranean region (i.e. after the Nile river) and represent $80 \%$ of the GoL catchment area (Molliex et al., 2014). Following the construction of the Aswan High dam on the Nile river, the Rhone river represent nowadays, the major source of fresh water, and organic carbon input to the Mediterranean Sea (Sempéré et al., 2000). In the GoL, numerous studies have been conducted to understand the processes governing the input, transport and fate of sediment from land to the oceanic environment via rivers (Cathalot et al., 2010; Kim et al., 2006; Tesi et al., 2007). These efforts have shown that allochtonous material supplied by rivers is a heterogeneous and complex mixture mainly composed of terrestrial organic components which are buried within pro-deltaic accumulations. Sediments in Gol's pro-delta are characterized by very low $\delta^{13} \mathrm{C}_{\text {org }}$ values ( $\sim-25 \%$ ) and high sedimentation rates $\left(20 \mathrm{~cm} \mathrm{yr}^{-}\right.$ ${ }^{1}$; Radakovitch et al., 1999), in contrast to the open ocean production (primary producers and derived outcomes), which is characterized by heavier values of $-22 \%$ at the shelf break. According to the shelf distribution, the $\delta^{13} \mathrm{C}$ signature of organic carbon isotopes $\left(\delta^{13} \mathrm{C}_{\text {org }}\right)$ in sediments can be interpreted as reflecting the relative proportion of terrestrial carbon organic particulates versus marine production (i.e. seaward dilution), and therefore can be used as an indicator of the terrigenous flux into the basin (Meyers, 1994).

\subsection{Samples pre-analyses treatment and analytical method.}

Following the sub-sampling of the borehole, sediments were freeze-dried prior to any treatment. A portion of dried samples $(1.5 \pm 0.1 \mathrm{~g})$ was ground in agate mortar, and transferred to pre-cleaned $15 \mathrm{~mL}$ centrifuge tubes. Prior to elemental and isotopic analyses, carbonate fraction was removed by dissolution in excess $2 \mathrm{~N} \mathrm{HCl}$ for 24 hours at room temperature (Pasquier et al., 2018). During digestion, centrifuge tubes were placed in ultrasonic bath to increase the mechanical separation of clay and calcium carbonate. After 
digestion, residues were washed three times with distilled water, centrifuged and dried at $50^{\circ} \mathrm{C}$. Few hours before analyses, samples were weighed in tin capsules.

All analyses were performed using an elemental analyser (EA, Flash 2000 - Thermo Scientific) coupled to an isotope ratio mass spectrometer (Delta V plus, Thermo Scientific EAIRMS) at the Pôle de Spectométrie Océan (PSO, Brest, France). Samples were loaded into an auto-sampler for automatic analysis. During analyses, samples were dropped into the oxidation furnace maintained at temperature of $1020^{\circ} \mathrm{C}$, and were combusted in the presence of excess oxygen $\left(240 \mathrm{ml} \mathrm{min}^{-1}\right)$ for 8 s. Flash combustion products were carried with a Helium flow $\left(100 \mathrm{ml} \mathrm{min}^{-1}\right)$ prior to entering into the mass spectrometer via a Conflo IV system (Thermo Scientific).

$\delta^{15} \mathrm{~N}$ and $\delta^{13} \mathrm{C}$ are given as the per mil deviation (\%) from the $\mathrm{N}$-isotopes of atmospheric $\mathrm{N}_{2}$, and per mil deviation (\%o) from the PDB standard. Routine replicate measurements shows internal reproducibility less than $0.1 \%$ o $(2 \sigma)$ for standards and $0.6 \%$ o $(2 \sigma)$ for replicate samples; and $0.1 \% \circ(2 \sigma)$ for standards and $0.3 \%$ o $(2 \sigma)$ for replicate samples, respectively for nitrogen and carbon.

Total nitrogen and total organic carbon percentage (respectively TN and TOC) were measured using the Thermal Conductivity Detector (TCD) of the Flash EA 2000, ThermoScientific. Therefore, throughout this manuscript TOC and TN refer to the residual organics in sediment after carbonate extraction by $\mathrm{HCl}$ leaching. Repeated measurements show an internal reproducibility of less than $0.02 \%(2 \sigma)$ and $0.5 \%(2 \sigma)$ on standards replicate analyses respectively for nitrogen and carbon, and less than $0.02 \%(2 \sigma)$ for both nitrogen and carbon on replicate samples.

\subsection{Chronology}

The chronostratigraphical framework of PRGL 1-4 used in this study is based on Sierro et al. (2009) chronology which used planktic (G. bulloides; Sierro et al., 2009) and benthic (H. baltica; J.F. Sierro unpublished data) $\delta^{18} \mathrm{O}$ measurements. PRGL's foraminifera oxygen isotopes curves, both planktic and benthic, reveal distinct end-members characterizing interglacials (low $\delta^{18} \mathrm{O}$ ) and glacials (high $\delta^{18} \mathrm{O}$ ) (Fig. 2). The updated age model for the last two climatic cycles (ca. 200 kyr) is based on close similarities between PRGL1-4 
planktic/benthic $\delta^{18} \mathrm{O}$ and synthetic Greenland record of Barker et al., 2011 (GL T $^{-}$ syn,GICC05/NALPSSpeleo age; Fig. 2, Table 1). Such a synchronization was previously used to produce accurate chronologies along the Iberian margin (Hodell et al., 2013; Margari et al., 2014) and in the Western Mediterranean Sea (Toucanne et al., 2015).

Sedimentation rates for PRGL 1-4 ranges between 0.14 and $2.3 \mathrm{~m} \mathrm{ka}^{-1}$, during interglacials and glacials repectively, with an average of $0.7 \mathrm{~m} \mathrm{ka}^{-1}$ over the entire studied interval. Such marine accumulation rate discrepancy resulted from the landward/seaward migrations of the shoreline and rivers' prodelta on the GoL shelf. High prodeltaic sedimentation on the outer shelf/upper slope occured during glacials at PRGL 1-4 (i.e. low sea level), while open marine regime with reduced terrigenous accumulation rates dominated during interglacials (i.e. high sea level).

\section{Results and discussion}

3.1. General interpretation of proxies $\left(\delta^{13} C_{\text {org }}-\delta^{15} N_{\text {tot }}\right)$.

Figure 3 shows the measurements of organic proxies $\left(\delta^{13} \mathrm{C}_{\mathrm{org}}, \delta^{15} \mathrm{~N}_{\text {tot, }}\right.$ TOC and TN; Fig. $3 c, d, e, f$ ) in parallel to oxygen isotopes of planktonic G. bulloides species (Sierro et al., 2009; Fig. 3a) and linear sedimentation rate (Fig. 3g) from the same core, and the reconstructed sea level from the Red Sea (Grant et al., 2014) (Fig. 3b). The $\delta^{13} C_{\text {org }}$ values at PRGL 1-4 range from $-25.4 \%$ o to $-21.6 \%$ with an average of $\sim-24.1 \%$. The lightest values in $\delta^{13} C_{\text {org }}$ are observed during glacial times, especially during glacial maxima (i.e. heavy $\delta^{18} \mathrm{O}$ values, MIS 2 , MIS 6a). $\delta^{15} \mathrm{~N}_{\text {tot }}$ is characterized by values ranging from $2.3 \%$ o to $4.0 \%$ o (average of $3.1 \%$ ) with strong depletion (up to $1 \%$ ) associated with glacial maxima. During these intervals, ${ }^{15} \mathrm{~N}_{\text {tot }}$ values drop below $3 \%$ suggesting sub-oxic/anoxic environment in modern ocean, i.e. oxygen minimum zones (OMZ; Ader et al., 2014). At site PRGL 1-4 this is supported by the occurrence of benthic foraminifera Brizalina dilatata (Cortina et al., 2011), and very high sedimentation rates (i.e. approx 20 -fold as compared to interglacial times) which can typically create $\mathrm{O}_{2}$-deficient zones. Indeed, consumption of oxygen in water column is also linked to the biological oxygen demand fueled by degrading organic matter from thriving primary producers in high terrigenous input and nutrient rich environment (Rabouille et al., 2008). Sediment deposited at PRGL 1-4 site are poor in organic matter $(0.6 \%$ of mean TOC and $0.08 \%$ of mean $\mathrm{TN}$ ) and no clear relationship is observed between the organic content and 
climate changes and/or sea-level (Fig. 3e and f), and with the sedimentation rates (Fig. 3g) (see also Supplementary Fig. 1 and 2). This is unexpected considering significant sedimentary input from the Rhone River and the seaward migration of coastal rivers' mouth (i.e. including the Rhone) during glacial lowstands (Mauffrey et al., 2015). High bacterial activity, and the use of organic carbon as electron donor by sulfate reducing bacteria could explain this observation. Indeed, during glacial periods, enhanced sedimentation of fine material (i.e. low porosity) with increased burial of fresh organic matter at the sediment/water interface drove an increase in early diagenetic processes. Consequently a higher proportion of organic matter is degraded, thus leading to low TOC content in the sediment and unusable C: $\mathrm{N}$ ratio (Pasquier et al., 2017) (see Supplementary Fig. 3).

Interestingly, organic carbon isotopes show significant fluctuations in phase with global climate changes, suggesting that $\delta^{13} C_{\text {org }}$ at PRGL 1-4 is climate sensitive. We show hereafter that these changes can improve our understanding of the paleo-hydrological changes in the Northwestern Mediterranean Sea over the last 200 kyr.

\subsection{Detailled signals recorded in organic matter isotopes $\left(\delta^{13} \mathrm{C}_{\text {org }}-\delta^{15} \mathrm{~N}_{\text {tot }}\right)$}

\subsubsection{Last Glacial Period (MIS 2/4)}

During the last glacial period (i.e MIS 2/4, 14-71 ka), dry conditions and low vegetation cover prevailed in the Mediterranean basin, as well as around the Alpine ice cap, and in the Rhone watershed (Beaudouin et al., 2005, 2007; Tzedakis et al., 2006; Sanchez-Goni et al., 2002). Lowstand sea level conditions at PRGL1-4 can be inferred from both the benthic foraminifera $\delta^{18} \mathrm{O}$ values (increase of $2.5 \%$ ) and the seismic record of paleoshoreline position (Rabineau et al., 2005, 2006; Jouet et al., 2006) (Fig. 2). The recorded glacial - interglacial isotopic variability exceeds the attendant sea level variation (ca. $0.87-1.4 \%$ o for a $110-130$ $\mathrm{m}$ sea-level change; Waelbroeck et al.,2002), suggesting involvement of additional factors such as temperature and local hydrography. For this period, $\delta^{13} \mathrm{C}_{\mathrm{org}}$ fluctuations are consistent with both benthic and planktic foraminifera $\delta^{18} \mathrm{O}$ profiles, and also the sea level variations. Indeed, $\delta^{13} \mathrm{C}_{\text {org }}$ characterizing pro-deltaic values $(-24.7 \%$ ) are observed at the end of the last glacial (i.e. 18-24 ka) following a continuous drop beginning at $50 \mathrm{ka}$. This decreasing trend in $\delta^{13} \mathrm{C}_{\text {org }}$ is interpreted as reflecting higher proportion of land-derived particulate organic matter at our site in response to the attendant sea level fall. The positive 
correlation $\left(R^{2}=0.55\right)$ observed between sea level and $\delta^{13} C_{\text {org }}$ over MIS 2/4 (14-71 ka; Fig. 4) highlight this relationship and suggest, by extension, that the organic carbon isotopic composition at PRGL 1-4 is controlled by glacio-eustatic changes at orbital timescale.

The changes in $\delta^{13} \mathrm{C}_{\text {org }}$ closely mirror the milllennial-scale climatic variability (Fig. 5). During MIS 3, PRGL $\delta^{18} \mathrm{O}$ profiles record rapid cooling and warming events, interpreted as stadial (including Heinrich stadials, HS) and interstadial period, respectively (Sierro et al., 2009) (Fig. 5a). Sierro et al. (2009) used PRGL1-4 $\delta^{18}$ O record and condensed layers (i.e foram-rich sandy layers with very low sedimentation rate), to revisit the timing of the $20-30 \mathrm{~m}$ sea-level fluctuations described in the Red Sea by Siddall et al. (2003) and Arz et al. (2007), and suggested that sea-level drop and seaward migration of pro-deltaic accumulation in the GoL occurred at the time of cooling interval and the Heinrich Stadial in particular. These intervals are recognizable in the borehole by positive $\delta^{18} \mathrm{O}$ excursion and higher abundance of Neogloboquadrina pachyderma (Sierro et al., 2009). This period is also characterized by a $1-$ $1.5 \%$ decrease in $\delta^{13} \mathrm{C}_{\text {org }}$ values, particulary during HS 6, $5(\mathrm{a}, \mathrm{b})$ and 4 , indicating higher proportion of land-derived organic matter that is consistent with Sierro et al. (2009)'s conclusions. In contrast, periods of maximum flooding (interstadials 4, 8, 14 and 16) are characterized by increase $\delta^{13} \mathrm{C}_{\text {org }}$ consistent with a reduction in land-derived material due to the preceding landward migration of the prodeltaic depocentre. Thus, our data support the conclusions of Sierro et al. (2009) about the timing of sea-level changes during MIS 3.

\subsubsection{Warm substages of the Last interglacial (MIS 5).}

Our results show heavier $\delta^{13} C_{\text {org }}$ (up to $22 \%$ o) during MIS 5 ( 71-130 ka), indicative of increased marine influence in comparaison to glacial intervals (for e.g. MIS 2 glacial maxima). Specifically, three $\delta^{13} C_{\text {org }}$ peaks occurred during the interglacial warm substages (MIS 5e,c,a) and associated sea level highstands (Waelbroeck et al., 2002; Grant et al., 2014). Such $\delta^{13} C_{\text {org }}$ values are consistent with the attendant decreased seaward sediment transfer and maximum landward migration of coastal rivermouths in the Northwestern Mediterranean Sea during interglacials (Bonneau et al., 2014; Rabineau et al., 2006). Subsequent climate cooling (MIS $5 d$ and $b$ ) show the inverse pattern (i.e. increased riverine inputs and seaward migration of coastal rivermouths) as shown by significant decrease in $\delta^{13} C_{\text {org }}$ (Fig. 3). This pattern is consistent with that described for the last glacial as shown in the previous section. 
Surprinsingly, the successive interglacial warm substages (MIS $5 e$, c a) show an unexpected $\delta^{13} \mathrm{C}_{\text {org }}$ increase of $\sim 3 \%$ from $130 \mathrm{ka}$ to $82 \mathrm{ka}$ as compared to the sea-level variation. Indeed, the highest sea-level condition described during the MIS 5e (Waelbroeck et al., 2002; Grant et al., 2014) does not correspond to the most important marine signature in $\delta^{13} C_{\text {org }}$ at PRGL 1-4 site (Fig. 3c). This signature is in fact observed later, during MIS $5 a$ warm substage, when the sea-level was about $40 \mathrm{~m}$ lower in comparison to MIS 5e. A sealevel amplitude of $40 \mathrm{~m}$ correspond to one third of the glacial - interglacial eustatic variability (Waelbroeck et al., 2002; Grant et al., 2014) and to a shoreline change of around $20 \mathrm{~km}$ in the GoL. The described pattern can be nicely illustrated by the strong inverse relationship $\left(R^{2}=0.73\right)$ recorded between sea-level and $\delta^{13} C_{\text {org }}$ during the MIS 5 warm substages (Fig. 4). As a result, we conclude that the impact of sea-level on the $\delta^{13} C_{\text {org }}$ signature described during MIS $2 / 4$ is possibly overwhelmed by an additional forcing during MIS5. We assume that the sediments during MIS 5 warm substages have preserved important proportion of terrestrial land-derived organic carbon particulates (low $\delta^{13} \mathrm{C}_{\text {org }}$ ) due to high river runoff. The gradual decrease in $\delta^{13} \mathrm{C}_{\text {org }}$ during the course of the MIS 5 warm substages likely indicate a gradual reduction of riverine delivery through the last Interglacial, with the highest runoff during MIS 5e. A detailed observation of $\delta^{13} \mathrm{C}_{\mathrm{org}}$ during the warm stages of the MIS 5 (i.e. increasing $\delta^{13} C_{\text {org }}$ values throughout the substage, e.g. MIS $5 e, c$ ) suggest enhanced riverine inputs at the onset of the intervals (highlighted with red arrows on the Fig. 6c). Peaks in coastal river runoff during interglacial warm substages of the last half million years have previously been highlighted by Toucanne et al. (2015) on the Eastern Corsica margin, with concomitant high amount of $\mathrm{OM}$ arrival at the continental slope especially during MIS 5e, and relatively lesser during MIS 5c and 5a (Fig. 6e). At PRGL1-4 site, the organic carbon (i.e. \% TOC) is not well preserved during MIS 5e and c (see discussion above) but attendant $\delta^{15} \mathrm{~N}$ lows suggest high river runoff and possible past local dysoxia to anoxia (i.e. $\mathrm{OMZ}$ development; $\delta^{15} \mathrm{~N}<3 \%$ ). Indeed, in present day $\mathrm{OMZs}$, when nitrate $\left(\mathrm{NO}_{3}{ }^{-}\right)$ consumption does not reach completion, a net ${ }^{15} \mathrm{~N}$-enrichement of the residual $\mathrm{NO}_{3}{ }^{-}$pool is observed (Voss et al., 2001). In those highly productive environments, the water column produces low $\delta^{15} \mathrm{~N}$ organic matter as we observe during the MIS 5 warm substages $\left(\delta^{15} \mathrm{~N}_{\text {tot }}\right.$ around $3-2.5 \%$ ), where $\delta^{15} \mathrm{~N}_{\text {tot }}$ reached similar values as those observed during glacial maxima (i.e. MIS 2 and MIS 6a). Taken together, these results point to enhanced riverine 
inputs in the GoL and surrounding regions (including Corsica) during the warm substages of MIS 5. The temporal decrease of riverine inputs during the MIS 5 warm periods (i.e. $\delta^{13} C_{\text {org }}$ MIS $5 e$ > MIS $5 c>$ MIS 5a) could reveal a possible forcing of the decreasing eccentricity through time, with a positive correlation between eccentricity and rainfall levels (Dixit et al, submitted) (Fig. 2).

\subsubsection{Warm substages of the MIS 6 .}

Detailed observation of our proxies for MIS 6 reveal enhanced riverine inputs during MIS 6 warm substages, MIS $6 \mathrm{~d}$ and $\mathrm{b}$ as indicated by low $\delta^{13} \mathrm{C}_{\text {org, }}$ low $\delta^{15} \mathrm{~N}$, high TOC (Fig. 3a,c,d). Depleted planktic $\delta^{18} \mathrm{O}$ values (equivalent or lower than that observed during MIS 5e) during these intervals corroborate our interpretation (black arrows on Fig. $2 b$ and c). Our evidence for increased river runoff/rainfall $\left(\delta^{13} \mathrm{C}_{\text {org }}, \delta^{15} \mathrm{~N}, \mathrm{TOC}\right)$ in the GoL is strongly supported by the correlation with Corsican proxies for increased flux of terrestrial materials during this period (Fig. 6e Toucanne et al., 2015). It is interresting to note that no evidence for high riverine input during MIS 3 is seen in the PRGL1-4 record, suggesting different mechanisms operating during the last two glacial periods.

\subsection{Comparison with regional paleoclimatic records}

Specific episodes of enhanced proportion of land-derived material regardless of sea-level conditions suggest enhanced Rhone river activity during the warm intervals of both MIS 5 and MIS 6. Therefore our results imply significant increase in precipitation amount over the GoL catchment area during these periods. This assumption agrees with previously described high rainfall intervals recorded in continental and marine deposits from the surrounding areas. Increased proportion of continental organic matter (i.e. low $\delta^{13} \mathrm{C}_{\text {org }}$, low $\delta^{15} \mathrm{~N}$, high TOC) are synchronous with periods of speleothem growth in both Villars and Clamous speleothems during warm intervals of MIS 5 and the glacial MIS 6d (southern France; Plagnes et al., 2002; Wainer et al., 2013) (Fig. 6a). All pluvial phases are also recorded with a significant $\delta^{13} \mathrm{C}$ depletion in Spain (Gitana cave; Hodge et al., 2008) (Fig. 6b). Recently, Regattieri et al. (2015) reported wetter conditions in central Italy during the first half of the MIS 5c, by using oxygen isotopic composition of the Sulmona paleo-lake carbonates, as well as in central Italy speleothems during MIS 5e and MIS 6b (Antro del Corchia; Drysdale et al., 
2005; and Tana Che Urla, Regattieri et al., 2014) (Fig. 6f). Similarly, Bard et al. (2002) revealed pluvial conditions in the Western Mediterranean basin during MIS 6d, ca. 175 ka (Argentarola basin) which are synchronous with salinity decrease in the central Adriatic basin and in the Eastern Tyrrhenean Sea (see respectivelly Piva et al., 2008 and Kallel et al., 2000) (Fig. 6f). This indicate that the increase in precipitation observed in GoL during warm intervals of the MIS 5 and MIS 6 likely recorded regional increase in precipitation over the Western Mediterranean basin.

Interestingly these events are also coeval with high rainfall amount from Levant speleothems caves (Soreq and Peqiin; Ayallon et al., 2002; Bar-matthews et al., 2003) and increased runoff from North African river systems, including the Nile River (Revel et al., 2010; Rohling et al., 2002) (Fig. 6g and h). This is nicely illustrated through the covariation of PRGL1-4 pluvial events and the XRF-core scanner Ba/Al ratio from IODP 968, which are believed to indicate periods of sapropel deposition (Ziegler et al., 2010) (Fig. 6g). Thus, a synchronicity exists between increased GoL runoff and peaks in the North African summer monsoon (i.e. ITCZ northward position), which further highlight a close coupling between mid- and low-latitude climate systems, that remains to be explained. While the North African river runoff variability is controlled by the monsoon system, which is associated with the latitudinal ITCZ fluctuations (up to $25^{\circ} \mathrm{N}$; Rohling et al., 2002; Tuenter et al., 2003), the GoL river runoff $\left(\sim 43^{\circ} \mathrm{N}\right)$ is controled by the North Atlantic system and associated autumn/winter cyclogenesis activity (Moreno et al., 2005; Reale et al., 2001; Spotl et al., 2010; Struglia et al., 2004; Trigo et al., 2002).

The Rhone river is the largest GoL river (first Mediterranean river since Nile damming) flowing through the French part of the European Alps. Owing to its key location between the North Atlantic and Eastern Mediterranean, the GoL catchment is under the influence of complex atmospheric interactions. The southern part is under the influence of a Mediterranean climate characterized by autumn and spring rainfall (i.e. so-called 'Mediterranean flood'; Hurrell, 1995; Martin-Vide and Lopez-Bustins, 2006), whereas the northern part experiences oceanic conditions, with rainfall during winter (Etchevers et al., 2002). In this area, enhanced rainfall activity during winter mainly results from increased passage of North Atlantic atmospheric depressions. In the Alps, precipitation occurred mainly during winter, and floods during early spring snowmelt events. Over the last thousand years, 
North Atlantic Oscillations (NAO) is the dominant atmospheric phenomena in the North Atlantic sector (Olsen et al., 2012), including the northern part of the GoL catchment area (Hurrell, 1995; Trigo et al., 2002) (Fig. 1). Fluctuations in NAO strongly affects the intensity of zonal flows over the North Atlantic (i.e. westerlies), the position of storm tracks and subsequent precipitation amount across Europe and the Mediterranean basin (Hurrell and Van Loon, 1997; López-Moreno et al., 2011). During negative phase of NAO, storm tracks are shifted southwards, thus bringing wet and mild winter over southern Europe (Fig. 1). Therefore, NAO negative phase correspond to more penetration of warm and moist Atlantic air masses towards the Rhone watershed (i.e. $80 \%$ of the GoL catchment). Nowadays, the NAO variability explain a large part of the inter-annual Rhone discharge variability, i.e. up to 45\% during winter (Struglia et al., 2004 and reference therein). Revillon et al., 2008 used radiogenic isotopes ( $\mathrm{Sr}$ and $\mathrm{Nd}$ ) to show that the sediments deposited at PRGL1-4 during MIS 5 were mainly derived from the Rhone watershed and the Alps in particular. These data attest a strong sediment transport from the northern part of the Rhone catchment area during MIS 5 and therefore indicate, by extension, that the contribution of the southern part of the Rhone watershed, in which the Mediterranean flood happened, is minor in comparison. In other words, sediment provenance during periods of increased rainfall/runoff in the GoL corroborates with the origin of winter Atlantic moisture during MIS 5 and MIS 6 warm periods, in response to more frequent negative NAO-like.

The above lines of evidence suggest a direct addition of extra-Mediterranean (i.e. Atlantic) water into the Mediterranean Sea during warm substages of the last $200 \mathrm{kyr}$ and during periods of northward position of the ITCZ. Hence, our findings give some additional constraint on the role of mid-latitude Atlantic influences and forcing yielding to the sapropel deposition. First by increasing the seaward export of terrestrial organic matter through river runoff, which significantly influenced the primary productivity $\left(\delta^{15} \mathrm{~N}\right.$ depletion) and the subsequent organic carbon flux to the sea-floor (Rohling and Hilgen, 1991). Second by adding 'extra-Mediterranean water' that possibly helped to create the necessary basin scale hydrographic disruption by reducing intermediate and deep water ventilation. Indeed, the oceanic response to increase freshwater flux is a reduction in salinity and mixed layer depth that lead to stronger stratification and less Western Mediterranean Deep Water formation (i.e. WMDW; Meijer and Tuenter, 2007; Rohling et al., 2015 and reference therein). According 
to Millot (1999) and Rohling et al. (2015), changes in salinity in the GoL has strong impact on the Bernouilli aspiration depth and WMDW formation, the primary mechanisms involved in the removal of deep water from the Western Mediterranean basin causing WMDW stagnation. This deep-water stagnation, at times of GoL pluvial events, induced progressive deep-water oxygen depletion that could lead to enhanced preservation of terrestrial inputs and/or enhanced biological production, which are both confirmed by our isotopic proxies (i.e. $\delta^{13} \operatorname{Corg}$ and $\delta^{15} \mathrm{~N}$, respectively). Addition of 'extra-Mediterranean water into the GoL is consistent with results by Scrivner et al. (2004) who showed through a geochemical approach that the Nile was probaly not the only source affecting the Mediterranean freshwater budget before/during sapropel deposition. Penetration of direct Atlantic moisture into the Western Mediterranean basin has also been identified by Kutzbach et al. (2014) and Bosmans et al. (2015) which is a necessary condition for increased North Mediterranean borderland's cyclogenesis (i.e. from Corsica to Turkey; Rohling and Hilgen, 1991; Toucanne et al., 2015; Reale et al., 2001; Kallel et al., 2000,1997; Bard et al.,2002; Drysdale et al., 2007; Zanchetta et al., 2007; Regattieri et al., 2014, 2015, 2017). Our study suggests that Rhone river could have played a significant role in the necessary forcing for sapropel deposition. Organic matter isotopic study cannot be used to quantify the impact of fresh-water addition on the WMDW formation, so the exact role of Atlantic origin feshwater during those periods need further investigation.

\section{Conclusion}

In this study, we used an innovative approach of bulk isotope measurements to determine the nature of the organic matter preserved in the Gulf of Lion sediments, with the aim to better assess the variation in the regional rivers input during the past 200 kyr.

Our results reveal that sea-level, through its role in both seaward and landward migration of prodeltaic accumulation, was a significant forcing, at both orbital and millenial timescales, on the export of terrigenous organic matter in the GoL sediments. As a prominent example, during MIS 3 interstadials, we observed decreased proportion of land-derived materials that support concomitant flooding events and, by extension, the Sierro et al., (2009)'s interpretation regarding millenial-scale eustatic sea-level variation of the last glacial cycle. 
Interestingly, this relationship between sea-level and proportion of land-derived organic matter seems to be overwhelmed by additional processes during warm substages of MIS 5 and MIS 6, where high sea-level conditions correspond to high proportion of terrestrial OM (i.e. low $\delta^{13} \mathrm{C}_{\text {org }}$ ). At that time, GoL sediment are also characterized by low $\delta^{15} \mathrm{~N}$ which support the idea of local dysoxia - anoxia at the Gol' shelf break, as a direct consequence of high terrigenous/nutrient inputs. These evidence point to high precipitation levels over the GoL catchment area, in particular over the Rhone watershed.

Given the nature of Atlantic-derived rainfall in most of the Rhone catchement area (excluding the southern part), we argue for intense runoff of extra-Mediterranean, i.e. Atlantic, freshwater into the Gulf of Lion during the warm substages of MIS5 and MIS6. Comparison with regional paleohydrological records from the northern Mediterranean borderlands reveals the regional character of these pluvial events. Our data also suggests that high rainfall events over the GoL catchement area and the Northern Mediterranean borderland occurred at time of North African summer monsoon and the sapropel deposition in the Mediterranean basin, thus highlighting a close coupling between mid- (North Atlantic) and low-latitudes (monsoon) climate systems. Finally, we assume that our data provide additional constraints on the genesis of sapropel deposition. First, Northern Mediterranean Rivers increased the organic matter flux to the sea floor through river runoff, with possible impact on the marine productivity. Secondly, the addition of fresh water into the western Mediterranean basin, where WMDW form, may have lead to perturbation of the Mediterranean hydrological cycle inducing reduction of the deep-water ventilation.

\section{Acknowledgements}

The authors warmly acknowledge O. Lebeau for assistance on the EA-IRMS in Brest; E. Regattieri kindly provided data respectively from Italian continental records and an European speleothems database; A. Cortina, F. Sierro, JP. Suc for helpful discussions during various steps of this work; S. Barker for providing the most updated age model related to the Greenland synthetic $\delta^{18} \mathrm{O}$ record $\mathrm{GL}_{\mathrm{T}}$-syn.

This work was supported by the "Laboratoire d'Excellence" LabexMER (ANR-10-LABX-19) and co-funded by a grant from the French government under the program "Investissements d'Avenir", and by a grant from the Regional Council of Brittany. The European Promess 
shipboard party and colleagues at Ifremer are also thanked for previous contributions of data acquisition and processing.

All data reported in this study are available at PROMESS pangea website (http://www.pangea.de/?q=PROMESS1).

\section{Legend caption: ( 6 figures +1 table +1 supplementary figure)}

Figure 1 (A). Location of the main sites mentioned in the text, including our study site PRGL1-4 (red circle) and Rhone river catchment area (blue line and grey area). Brown and blue circles (with associated names) represent continental and marine records. The red line over North Africa show the maximum northward displacement of the ITCZ over the last million years from Tuenter et al. (2003). Course of the Central Saharan rivers according to Coulthard et al. (2013). The general trajectory of the atmospheric westerlies is shown for NAO-positive and NAO-negative states according to the present day observations (B). Gulf of Lion shelf morphology, red circle corresponds to our study site PRGL1-4, blue line corresponds to the LGM coastline position.

Figure 2: (A) Greenland synthetic $\delta^{18} O$ record (GL $L_{T}$ syn; Barker et al., 2011); (B) $\delta^{18} O$ of planktonic species [G. bulloides] (Sierro et al., 2009); (C) $\delta^{18} O$ of benthic species [H. baltica] from PRGL1-4 site (J.F. Sierro unpublished data); (D) Red Sea sea level record (coreKLO9, red curve, grey line corresponds to maximum probability 95\%; Grant et al., 2014); (E) U ${ }^{k^{\prime}}{ }_{37}$-SST of combined record of core MD01-2444 and MD01-2443 (Iberian margin) yellow line (Martrat et al., 2007) and $C^{37}$ alkenones-SST from PRGL1-4 orange line (Cortina et al., 2015); (F) June insolation for $65^{\circ} \mathrm{N}$ (blue line) with precession (black line) and eccentricity of Earth's orbit (dashed grey line; Laskar et al., 2004). Black arrows highlight unexpected lower $\delta^{18} \mathrm{O}$ during MIS 6 warm substages; Top black crosses indicate $C^{14}$ dating and green triangles indicate position of tie-points (see Table 1). Grey bands indicate interglacial conditions s.l, dark grey bands indicate interglacial warm-periods. Termination (T.) according to Barker et al. (2011). Scheme of marine stage according to Railsback et al. (2015).

Figure 3: (A) $\delta^{18}$ O of planktonic species [G. bulloides] from PRGL1-4 (Sierro et al., 2009); (B) Red Sea sea level record (coreKLO9, red curve, grey line corresponds to maximum probability 95\%, Grant et al., 2014); (C) $\delta^{13} C_{\text {org }}$ of PRGL1-4, this study; (D) $\delta^{15} N_{\text {tot }}$ of PRGL1-4, this study; (E) \% of Total Organic Carbon (TOC), this study; (F) \% Total Nitrogen (TN); (G) Linear sedimentation rate (LSR) in $m k^{-1}{ }^{-1}$. Top black crosses indicate $C^{14}$ dating and green triangles indicate position of tie-points (see Table 1). Grey bands indicate interglacial conditions s.l, dark grey bands indicate interglacial warm-periods. Termination (T.) according to Barker et al. (2011). Scheme of marine stage according to Railsback et al. (2015).

Figure 4: $\delta^{23} C_{\text {org }}$ versus Relative Sea Level reconstruction in Red Sea (Grant et al., 2014). Blue circles correspond to MIS $2 / 4$ values ( $n=$ $103)$, orange circles to warm substages of MIS 5 ( $n=18)$ and green crosses to MIS 6 ( $n=176)$.

Figure 5: (A) $\delta^{18}$ O of planktonic species [G. bulloïdes] from PRGL1-4 (Sierro et al., 2009); (B) Red Sea sea level record (coreKL09, red curve, grey line corresponds to maximum probability 95\%, Grant et al., 2014); (C) Percentage of polar species Neogloboquadrina pachyderma (Sierro et al., 2009); (D) \% of fine sand (Sierro et al., 2009); (D) $\delta^{13} C_{\text {org }}$ of PRGL1-4, this study; (E) \% of Total Organic Carbon (TOC), this study. Top black crosses indicate $C^{14}$ dating and green triangles indicate position of tie-points (see Table 1). Grey bands indicate timing of ea-level flooding (Sierro et al., 2009). Green bands indicate timing of Heinrich stadials (Sierro et al., 2009). Termination (T.) according to Barker et al. (2011). Scheme of marine stage according to Railsback et al. (2015).

Figure 6: (A) Chronology of speleothem growth periods from Villars and Clamouse caves indicating humid period in South France (respectively Plagnes et al., 2002; Wainer et al., 2011); (B) $\delta^{13} \mathrm{C}$ record at Gitana cave (Spain; Hodge et al., 2008); (C) $\delta^{13} C_{\text {org }}$ of PRGL1-4, this study, Red arrows gradual increase of precipitation during MIS 5 warm susbstages; (D) $\delta^{15} N_{\text {tot }}$ of PRGL1-4, this study; (E) Abundance of 
benthic foraminifera show the deep-infaunal group (pink line) and XRF Ti/Ca from Corsica borehole GDEC4 (orange line in log scale, Toucanne et al., 2015); (F) $\delta^{18} O$ record from Tana Che urla (centrale Italy, light blue line; Regattieri et al., 2014), Argentarola (Tyrrhenian cost of Italy, dark blue line; Bard et al., 2002), Sulmona basin (aqua curve; Regattieri et al., 2015); (G) XRF Ba/Al (log scale, ODP968 - South Cyprus; Ziegler et al., 2010) and sapropel chronology (speleothem age-scale) according to Ziegler et al. (2010); (H) $\delta^{18} \mathrm{O}$ record of Soreq (Central Israel, black line; Bar-Matthews et al., 2003), Pepiin (north Israe,; grey line; Bar-Matthews et al., 2003); (I) $\delta^{18}$ O from Sanbao - Hulu cave (Asia; Wang et al., 2008). Brown bands indicate pluvial periods. Termination (T.) according to Barker et al. (2011). Scheme of marine stage according to Railsback et al. (2015).

Table 1: Chronological framework for PRGL1-4. Age of isotope events from the synthetic Ice Greenland (GL $\left.L_{T-s y n}\right)$ record of Barker et al. (2011). GI refer to Greenland Interstadial, MIS is Marine Isotope Stage and T correspond to Termination. Scheme of marine stage according to Railsback et al. (2015).

Supplementary Figure 1: (A) $\delta^{15} N_{\text {tot }}$ versus linear sedimentation rate; (B) $\delta^{15} N_{\text {tot }}$ versus \% fine sand (Sierro et al., 2009); (C) \% of Total Nitrogen (TN) versus linear sedimentation rate; (D) \% of Total Nitrogen (TN) versus \% fine sand (Sierro et al., 2009); (E) $\delta^{13} C_{\text {org }}$ versus linear sedimentation rate; (F) $\delta^{3} C_{\text {org }}$ versus \% fine sand (Sierro et al., 2009); (G) \% of Total Organic Carbon (TOC) versus linear sedimentation rate; (H) \% of Total Organic Carbon (TOC) versus \% fine sand (Sierro et al., 2009).

\section{References}

Ader, M., Sansjofre, P., Halverson, G.P., Busigny, V., Trindade, R.I.F., Kunzmann, M., Nogueira, A.C.R., 2014. Ocean redox structure across the Late Neoproterozoic Oxygenation Event: A nitrogen isotope perspective. Earth and Planetary Science Letters 396, 1-13. doi:10.1016/j.epsl.2014.03.042

Ariztegui, D., Asioli, A., Lowe, J.J., Trincardi, L., Tamburini, F., Chondrogianni, C., Accorsi, C.A., Bandini Mazzanti, M., Mercuri, A.M., Van der Kaars, S., McKenzie, J.A., Oldfield, F., 2000. Palaeoclimate and the formation of sapropel S1: inferences from Late Quaternary lacustrine and marine sequences in the central Mediterranean region. Palaeogeography, Palaeoclimatology, Palaeoecology 158, 215-240. doi:10.1016/S0031-0182(00)00051-1

Arz, H.W., Lamy, F., Ganopolski, A., Nowaczyk, N., Pätzold, J., 2007. Dominant Northern Hemisphere climate control over millennial-scale glacial sea-level variability. Quaternary Science Reviews 26, 312-321. doi:10.1016/j.quascirev.2006.07.016

Arz, H.W., Lamy, F., Pätzold, J., Müller, P.J., Prins, M., 2003. Mediterranean moisture source for an early-Holocene humid period in the northern Red Sea. Science 300, 118-121. doi:10.1126/science.1080325

Ayalon, A., Bar-Matthews, M., Kaufman, A., 2002. Climatic conditions during marine oxygen isotope stage 6 in the eastern Mediterranean region from the isotopic composition of speleothems of Soreq Cave, Israel. Geology 30, 303. doi:10.1130/00917613(2002)030<0303:CCDMOI>2.0.CO;2

Bader, J., Latif, M., 2003. The impact of decadal-scale Indian Ocean sea surface temperature anomalies on Sahelian rainfall and the North Atlantic Oscillation. Geophysical Research Letters 30, 602-4. doi:10.1029/2003GL018426

Bar-Matthews, M., Ayalon, A., Gilmour, M., 2003. Sea-land oxygen isotopic relationships from planktonic foraminifera and speleothems in the Eastern Mediterranean region and their implication for paleorainfall .... Geochimica et Cosmochimica Acta 67, 3181-3199. doi:10.1016/S0016-7037(02)01031-1

Bard, E., Delaygue, G., Rostek, F., Antonioli, F., 2002. Hydrological conditions over the 
western Mediterranean basin during the deposition of the cold Sapropel 6 (ca. $175 \mathrm{kyr}$ BP). Earth and Planetary Science Letters 202, 481-494. doi:10.1016/S0012821X(02)00788-4

Barker, S., Knorr, G., Edwards, R.L., Parrenin, F., 2011. 800,000 years of abrupt climate variability. Science 334, 347-351. doi:10.1126/science.1203580

Beaudouin, C., J-P. Suc, N. Acherki, L. Courtois, M. Rabineau, J-C. Aloïsi,. F. Sierro, C. Oberlin,, 2005 : First Palynological results from the northwestern Mediterranean shelf (Gulf of Lions) : a last climatic cycle vegetation record, Marine and Petroleum Geology, 22, 845-863.

Beaudouin, C., Jouet, G., Suc, J.-P., Berné, S., Escarguel, G., 2007. Vegetation dynamics in southern France during the last 30kyBP in the light of marine palynology. Quaternary Science Reviews 26, 1037-1054. doi:10.1016/j.quascirev.2006.12.009

Bonneau, L., Jorry, S.J., Toucanne, S., Silva Jacinto, R., Emmanuel, L., 2014. Millennial-Scale Response of a Western Mediterranean River to Late Quaternary Climate Changes: A View from the Deep Sea. The Journal of Geology 122, 687-703. doi:10.1086/677844

Bosmans, J., Drijfhout, S.S., Tuenter, E., 2015. Precession and obliquity forcing of the freshwater budget over the Mediterranean. Quaternary Science Reviews. doi:10.1016/j.quascirev.2015.06.008

Cathalot, C., Rabouille, C., Pastor, L., Deflandre, B., 2010. Temporal variability of carbon recycling in coastal sediments influenced by rivers: assessing the impact of flood inputs in the Rhône River prodelta. Biogeosciences 7, 1187-1205.

Cortina, A., Sierro, F.J., Flores, J.A., 2015. The response of SST to insolation and ice sheet variability from MIS 3 to MIS 11 in the northwestern Mediterranean Sea (Gulf of Lions). Geophysical Research Letters 42, 10366-10374. doi:10.1002/(ISSN)1944-8007

Cortina, A., Sierro, F.J., Gonzalez-Mora, B., Asioli, A., 2011. Impact of climate and sea level changes on the ventilation of intermediate water and benthic foraminifer assemblages in the Gulf of Lions, off South France, during MIS 6 and 7. Palaeogeography, Palaeoclimatology, Palaeoecology 309, 215-228. doi:10.1016/j.palaeo.2011.06.005

Coulthard, T.J., Ramirez, J.A., Barton, N., Rogerson, M., Brücher, T., 2013. Were Rivers Flowing across the Sahara During the Last Interglacial? Implications for Human Migration through Africa. PLoS ONE 8, e74834. doi:10.1371/journal.pone.0074834

Dixit, Y., Toucanne, S., Tripati, A., Lora, J., Fontanier, C., Pasquier, V., Bonnin, L., Jouet, G., Submitted for publication. Eccentricity forcing on the precession-derived Mediterranean rainfall during the past Interglacials.

Drysdale, R.N., Zanchetta, G., Hellstrom, J.C., 2005. Stalagmite evidence for the onset of the Last Interglacial in southern Europe at $129 \pm 1$ ka. Geophysical Research Letters. doi:10.1029/2005GL024658

Grant, K.M., Rohling, E.J., Ramsey, C.B., Cheng, H., 2014. Sea-level variability over five glacial cycles. Nature Communications 5. doi:10.1038/ncomms6076

Hodell, D., Crowhurst, S., Skinner, L., 2013. Response of Iberian Margin sediments to orbital and suborbital forcing over the past $420 \mathrm{ka}$. Paleoceanography 28, 185-199. doi:10.1002/palo.20017

Hodge, E.J., Richards, D.A., Smart, P.L., Andreo, B., 2008. Effective precipitation in southern Spain ( 266 to $46 \mathrm{ka}$ ) based on a speleothem stable carbon isotope record. Quaternary Research 69, 447-457. doi:10.1016/j.yqres.2008.02.013

Hurrell, J.W., 1995. Decadal Trends in the North Atlantic Oscillation: Regional Temperatures and Precipitation. Science 269, 676-679. doi:10.1126/science.269.5224.676 
Hurrell, J.W., Deser, C., 2009. North Atlantic climate variability: the role of the North Atlantic Oscillation. Journal of Marine Systems 78, 28-41. doi:10.1016/j.jmarsys.2008.11.026

Hurrell, J.W., Van Loon, H., 1997. Decadal variations in climate associated with the North Atlantic Oscillation. Climatic Change 36, 301-326.

Jo, K.-N., Woo, K.S., Yi, S., Yang, D.-Y., Lim, H.S., Wang, Y., Cheng, H., Edwards, R.L., 2014. Midlatitude interhemispheric hydrologic seesaw over the past 550,000 years. Chemical Geology 508, 378-382. doi:10.1038/nature13076

Jouet, G., Berné, S., Rabineau, M., Bassetti, M.A., Bernier, P., 2006. Shoreface migrations at the shelf edge and sea-level changes around the Last Glacial Maximum (Gulf of Lions, NW Mediterranean). Marine Geology 234, 21-42. doi:10.1016/j.margeo.2006.09.012

Kallel, N., Duplessy, J.C., Labeyrie, L., Fontugne, M., 2000. Mediterranean pluvial periods and sapropel formation over the last 200000 years. Palaeogeography, Palaeoclimatology, Palaeoecology 157, 45-58. doi:10.1016/S0031-0182(99)00149-2

Kallel, N., Paterne, M., Duplessy, J.C., 1997. Enhanced rainfall in the Mediterranean region during the last sapropel event. Oceanologica Acta 20,697-712.

Kandiano, E.S., Bauch, H.A., Fahl, K., 2014. Last interglacial surface water structure in the western Mediterranean (Balearic) Sea: Climatic variability and link between low and high latitudes. Global and Planetary Change. doi:10.1016/j.gloplacha.2014.10.004

Kim, J.H., Schouten, S., Buscail, R., 2006. Origin and distribution of terrestrial organic matter in the NW Mediterranean (Gulf of Lions): Exploring the newly developed BIT index. GeocheMIS try, Geophysics, Geosystems 7, 1-20. doi:10.1029/2006GC001306

Kutzbach, J.E., Chen, G., Cheng, H., Edwards, R.L., Liu, Z., 2014. Potential role of winter rainfall in explaining increased moisture in the Mediterranean and Middle East during periods of maximum orbitally-forced insolation .... Climate Dynamics 42, 1079-1095. doi:10.1007/s00382-013-1692-1

Laskar, J., Robutel, P., Joutel, F., Gastineau, M., Correia, A.C.M., Levrard, B., 2004. A longterm numerical solution for the insolation quantities of the Earth. A\&A 428, 261-285. doi:10.1051/0004-6361:20041335

Leroux, E., Rabineau, M., Aslanian, D., Gorini, C., 2017. High-resolution evolution of terrigenous sediment yields in the Provence Basin during the last $6 \mathrm{Ma}$ : relation with climate and tectonics. Basin Research 1-35. doi:10.1111/bre.12178

López-Moreno, J.I., Vicente-Serrano, S.M., Morán-Tejeda, E., Lorenzo-Lacruz, J., Kenawy, A., Beniston, M., 2011. Effects of the North Atlantic Oscillation (NAO) on combined temperature and precipitation winter modes in the Mediterranean mountains: Observed relationships and projections for the 21st century. Global and Planetary Change 77, 6276. doi:10.1016/j.gloplacha.2011.03.003

Magny, M., Nebout, N.C., 2013. Holocene changes in environment and climate in the central Mediterranean as reflected by lake and marine records. Preface. Climate of the Past 9, 1447-1454. doi:10.5194/cp-9-1447-2013

Margari, V., Skinner, L.C., Hodell, D.A., Martrat, B., 2014. Land-ocean changes on orbital and millennial time scales and the penultimate glaciation. Geology 42, 183-186. doi:10.1130/G35070.1

Martin-Vide, J., Lopez-Bustins, J.-A., 2006. The Western Mediterranean Oscillation and rainfall in the Iberian Peninsula. Int. J. Climatol. 26, 1455-1475. doi:10.1002/joc.1388

Martrat, B., Grimalt, J.O., Lopez-Martinez, C., Cacho, I., Sierro, F.J., Flores, J.A., Zahn, R., Canals, M., Curtis, J.H., Hodell, D.A., 2004. Abrupt Temperature Changes in the Western 
Mediterranean over the Past 250,000 Years. Science 306, 1762-1765. doi:10.1126/science.1101706

Martrat, B., Grimalt, J.O., Shackleton, N.J., de Abreu, L., 2007. Four climate cycles of recurring deep and surface water destabilizations on the Iberian margin. Science 317, 502-507. doi:10.1126/science.1139994

Mauffrey, M.A., Berné, S., Jouet, G., Giresse, P., Gaudin, M., 2015. Sea-level control on the connection between shelf-edge deltas and the Bourcart canyon head (western Mediterranean) during the last glacial/interglacial cycle. Marine Geology 370, 1-19. doi:10.1016/j.margeo.2015.09.010

Meijer, P.T., Tuenter, E., 2007. The effect of precession-induced changes in the Mediterranean freshwater budget on circulation at shallow and intermediate depth. Journal of Marine Systems. doi:10.1016/j.jmarsys.2007.01.006

Meyers, P.A., 1994. Preservation of elemental and isotopic source identification of sedimentary organic matter. Chemical Geology 114, 289-302.

Milner, A.M., Collier, R.E.L., Roucoux, K.H., Müller, U.C., Pross, J., Kalaitzidis, S., Christanis, K., Tzedakis, P.C., 2012. Enhanced seasonality of precipitation in the Mediterranean during the early part of the Last Interglacial. Geology 40, 919-922. doi:10.1130/G33204.1

Molliex, S., Rabineau, M., Leroux, E., Bourlès, D.L., Authemayou, C., Aslanian, D., Chauvet, F., Civet, F., Jouet, G., 2016. Multi-approach quantification of denudation rates in the Gulf of Lion source-to-sink system (SE France). Earth and Planetary Science Letters 444, 101115. doi:10.1016/j.epsl.2016.03.043

Moreno, A., Cacho, I., Canals, M., Grimalt, J.O., Sanchez Goñi, M.F., Shackleton, N., Sierro, F.J., 2005. Links between marine and atmospheric processes oscillating on a millennial time-scale. A multi-proxy study of the last 50,000yr from the Alboran Sea (Western Mediterranean Sea). Quaternary Science Reviews 24, 1623-1636. doi:10.1016/j.quascirev.2004.06.018

Olsen, J., Anderson, N.J., Knudsen, M.F., 2012. Variability of the North Atlantic Oscillation over the past 5,200 years. Nature Geosci. doi:10.1038/ngeo1589

Pasquier, V., Sansjofre, P., Rabineau, M., Houghton, J., Fike, D.A., 2017. Pyrite sulfur isotopes reveal glacial-interglacial environmental changes, Proceedings of the National Academy of Sciences of the United States of America, pp. 5941-5945. doi:10.1073/pnas.1618245114

Pasquier, V., Sansjofre, P., Liorzou, C., Rabineau, M., Lebau, O. 2018. Acid digestion on river influenced shelf sediment organic matter: Carbon and Nitrogen contents and isotopic ratios, Rapid Communication in Mass Spectrometry, doi: 10.1002/rcm.8014.

Piva, A., Asioli, A., Andersen, N., Grimalt, J.O., 2008. Climatic cycles as expressed in sediments of the PROMESS1 borehole PRAD1-2, central Adriatic, for the last 370 ka: 2. Paleoenvironmental evolution. Geochemistry, Geophysics, Geosystems. doi:10.1029/2007GC001713

Plagnes, V., Causse, C., Genty, D., Paterne, M., 2002. A discontinuous climatic record from 187 to $74 \mathrm{ka}$ from a speleothem of the Clamouse Cave (south of France). Earth and Planetary Science Letters 201, 87-103. doi:10.1016/S0012-821X(02)00674-X

Price, C., Stone, L., Huppert, A., 1998. A possible link between El Nino and precipitation in Israel. Geophysical Research Letters 25, 3963-3966.

Rabouille, C., Conley, D.J., Dai, M.H., Cai, W.J., Chen, C.T.A., Lansard, B., Green, R., Yin, K., Harrison, P.J., Dagg, M., McKee, B., 2008. Comparison of hypoxia among four riverdominated ocean margins: The Changjiang (Yangtze), Mississippi, Pearl, and Rhône rivers. 
Continental Shelf Research 28, 1527-1537. doi:10.1016/j.csr.2008.01.020

Rabineau, M., Berné, S., Olivet, J.L., Aslanian, D., 2006. Paleo sea levels reconsidered from direct observation of paleoshoreline position during Glacial Maxima (for the last 500,000 yr). Earth and Planetary Science Letters 252, 119-137. doi:10.1016/j.epsl.2006.09.033

Rabineau, M., Leroux, E., Aslanian, D., Bache, F., Gorini, C., Moulin, M., Molliex, S., Droz, L., Reis, dos, A.T., Rubino, J.L., Guillocheau, F., Olivet, J.L., 2014. Quantifying subsidence and isostatic readjustment using sedimentary paleomarkers, example from the Gulf of Lion. Earth and Planetary Science Letters 388, 353-366. doi:10.1016/j.epsl.2013.11.059

Radakovitch, O., Charmasson, S., Arnaud, M., 1999. $210 \mathrm{~Pb}$ and caesium accumulation in the Rhône delta sediments. Estuarine, Coastal and Shelf Sciences 48, 77-92.

Railsback, L.B., Gibbard, P.L., Head, M.J., 2015. An optimized scheme of lettered marine isotope substages for the last 1.0 million years, and the climatostratigraphic nature of isotope stages and substages. Quaternary Science Reviews 111, 94-106. doi:10.1016/j.quascirev.2015.01.012

Rasmussen, S.O., Andersen, K.K., 2006. A new Greenland ice core chronology for the last glacial termination. Journal of Geological Research 111, 1-16. doi:10.1029/2005JD006079

Reale, O., Feudale, L., Turato, B., 2001. Evaporative moisture sources during a sequence of floods in the Mediterranean region. Geophysical Research Letters 28, 2085-2088.

Regattieri, E., Giaccio, B., Zanchetta, G., 2015. Hydrological variability over the Apennines during the Early Last Glacial precession minimum, as revealed by a stable isotope record from Sulmona basin, Central .... J. Quaternary Sci. 30, 19-31. doi:10.1002/jqs.2755

Regattieri, E., Zanchetta, G., Drysdale, R.N., Isola, I., 2014. A continuous stable isotope record from the penultimate glacial maximum to the Last Interglacial (159-121ka) from Tana Che Urla Cave (Apuan Alps, central Italy). Quaternary Research 82, 1-12. doi:10.1016/j.yqres.2014.05.005

Révillon S., Bayon, G., Berne, S., Dennielou, B., Hémond, C., Jouet, G. Linking erosion rates and climatic variations in the Gulf of Lions, France: A geochemical approach. Goldschmidt Conference, Vancouver, July 2008

Revel, M., Ducassou, E., Grousset, F.E., 2010. 100,000 years of African monsoon variability recorded in sediments of the Nile margin. Quaternary Science Reviews. doi:10.1016/j.quascirev.2010.02.006

Rohling, E.J., Cane, T.R., Cooke, S., Sprovieri, M., 2002. African monsoon variability during the previous interglacial maximum. Earth and Planetary Science Letters 202, 61-75. doi:10.1016/S0012-821X(02)00775-6

Rohling, E.J., Hilgen, F.J., 2007. The eastern Mediterranean climate at times of sapropel formation: a review. Netherlands Journal of Geosciences/ ....

Rohling, E.J., Hilgen, F.J., 1991. The eastern Mediterranean climate at times of sapropel formation: a review. Geologie en Mijnbouw 70, 253-264.

Rohling, E.J., Marino, G., Grant, K.M., 2015. Mediterranean climate and oceanography, and the periodic development of anoxic events (sapropels). Earth Science Reviews 143, 6297. doi:10.1016/j.earscirev.2015.01.008

Rossignol-Strick, M., 1985. Mediterranean Quaternary sapropels, an immediate response of the African monsoon to variation of insolation. Palaeogeography, Palaeoclimatology, Palaeoecology 49, 237-263. doi:10.1016/0031-0182(85)90056-2

Rossignol-Strick, M., 1983. African monsoons, an immediate climate response to orbital insolation. Nature 304, 46-49. doi:10.1038/304046a0 
Sánchez Goñi, M., Cacho, I., Turon, J-L., Guiot, J., Sierro, F.J., Peypouquet, J-P., Grimalt, J.O., Shackleton, N.J., 2002. Synchroneity between marine and terrestrial responses to millennial scale climatic variability during the last glacial period in the Mediterranean region. Climate Dynamics 19, 95-105. doi:10.1007/s00382-001-0212-x

Scrivner, A.E., Vance, D., Rohling, E.J., 2004. New neodymium isotope data quantify Nile involvement in Mediterranean anoxic episodes. Geology 32, 565-4. doi:10.1130/G20419.1

Siddall, M., Rohling, E.J., Almogi-Labin, A., Hemleben, C., 2003. Sea-level fluctuations during the last glacial cycle. Nature. doi:10.1038/nature01687

Sierro, F.J., Andersen, N., Bassetti, M.A., Berné, S., 2009. Phase relationship between sea level and abrupt climate change. Quaternary Science Reviews 28, 2867-2881. doi:10.1016/j.quascirev.2009.07.019

Spotl, C., Nicolussi, K., Patzelt, G., Boch, R., 2010. Humid climate during deposition of sapropel 1 in the Mediterranean Sea: Assessing the influence on the Alps. Global and Planetary Change 71, 242-248. doi:10.1016/j.gloplacha.2009.10.003

Struglia, M.V., Mariotti, A., Filograsso, A., 2004. River discharge into the Mediterranean Sea: climatology and aspects of the observed variability. Journal of Climate 17, 4740-4751.

Svensson, A., Andersen, K.K., Bigler, M., 2008. A 60000 year Greenland stratigraphic ice core chronology. Climate of the Past 4, 47-57.

Tesi, T., MIS erocchi, S., Goñi, M.A., Langone, L., 2007. Source, transport and fate of terrestrial organic carbon on the western Mediterranean Sea, Gulf of Lions, France. Marine CheMIS try 105, 101-117. doi:10.1016/j.marchem.2007.01.005

Toucanne, S., Minto'o, C., Fontanier, C., Bassetti, M-A., Jorry, S. J., Jouet, G., 2015. Tracking rainfall in the northern Mediterranean borderlands during sapropel deposition. Quaternary Science Reviews 129, 178-195. doi:10.1016/j.quascirev.2015.10.016

Trigo, I.F., Bigg, G.R., Davies, T.D., 2002. Climatology of cyclogenesis mechanisms in the Mediterranean. Mon. Wea. Rev. 549-569. doi:10.1175/15200493(2002)130<0549:COCMIT>2.0.CO;2

Tuenter, E., Weber, S.L., Hilgen, F.J., Lourens, L.J., 2003. The response of the African summer monsoon to remote and local forcing due to precession and obliquity. Global and Planetary Change 36, 219-235. doi:10.1016/S0921-8181(02)00196-0

Tzedakis, P.C., 2007. Seven ambiguities in the Mediterranean palaeoenvironmental narrative. Quaternary Science Reviews 26, 2042-2066. doi:10.1016/j.quascirev.2007.03.014

Tzedakis, P.C., Hooghiemstra, H., Pälike, H., 2006. The last 1.35 million years at Tenaghi Philippon: revised chronostratigraphy and long-term vegetation trends. Quaternary Science Reviews 25, 3416-3430. doi:10.1016/j.quascirev.2006.09.002

Voss, M., Dippner, J.W., Montoya, J.P., 2001. Nitrogen isotope patterns in the oxygendeficient waters of the Eastern Tropical North Pacific Ocean. Deep Sea Research Part I 48, 1905-1921.

Waelbroeck, C., Labeyrie, L., Michel, E., 2002. Sea-level and deep water temperature changes derived from benthic foraminifera isotopic records. Quaternary Science Reviews

Wainer, K., Genty, D., Blamart, D., Bar-Matthews, M., Quinif, Y., Plagnes, V., 2013. Millennial climatic instability during penultimate glacial period recorded in a south-western France speleothem. Palaeogeography, Palaeoclimatology, Palaeoecology 376, 122-131. doi:10.1016/j.palaeo.2013.02.026

Wainer, K., Genty, D., Blamart, D., Daëron, M., 2011. Speleothem record of the last 180 ka in 21 
Villars cave (SW France): Investigation of a large $\delta 18$ O shift between MIS 6 and MIS 5 . Quaternary Science Reviews 30, 130-146. doi:10.1016/j.quascirev.2010.07.004

Wang, Y., Cheng, H., Edwards, R.L., Kong, X., Shao, X., 2008. Millennial-and orbital-scale changes in the East Asian monsoon over the past 224,000 years. Nature 451, 1090-1093. doi:10.1038/nature06692

Ziegler, M., Tuenter, E., Lourens, L.J., 2010. The precession phase of the boreal summer monsoon as viewed from the eastern Mediterranean (ODP Site 968). Quaternary Science Reviews 29, 1481-1490. doi:10.1016/j.quascirev.2010.03.011

Zanchetta, G., Drysdale, R.N., Hellstrom, J.C., 2007. Enhanced rainfall in the Western Mediterranean during deposition of sapropel S1: stalagmite evidence from Corchia cave (Central Italy). Quaternary Science Reviews 26, 279-286. doi:10.1016/j.quascirev.2006.12.003 


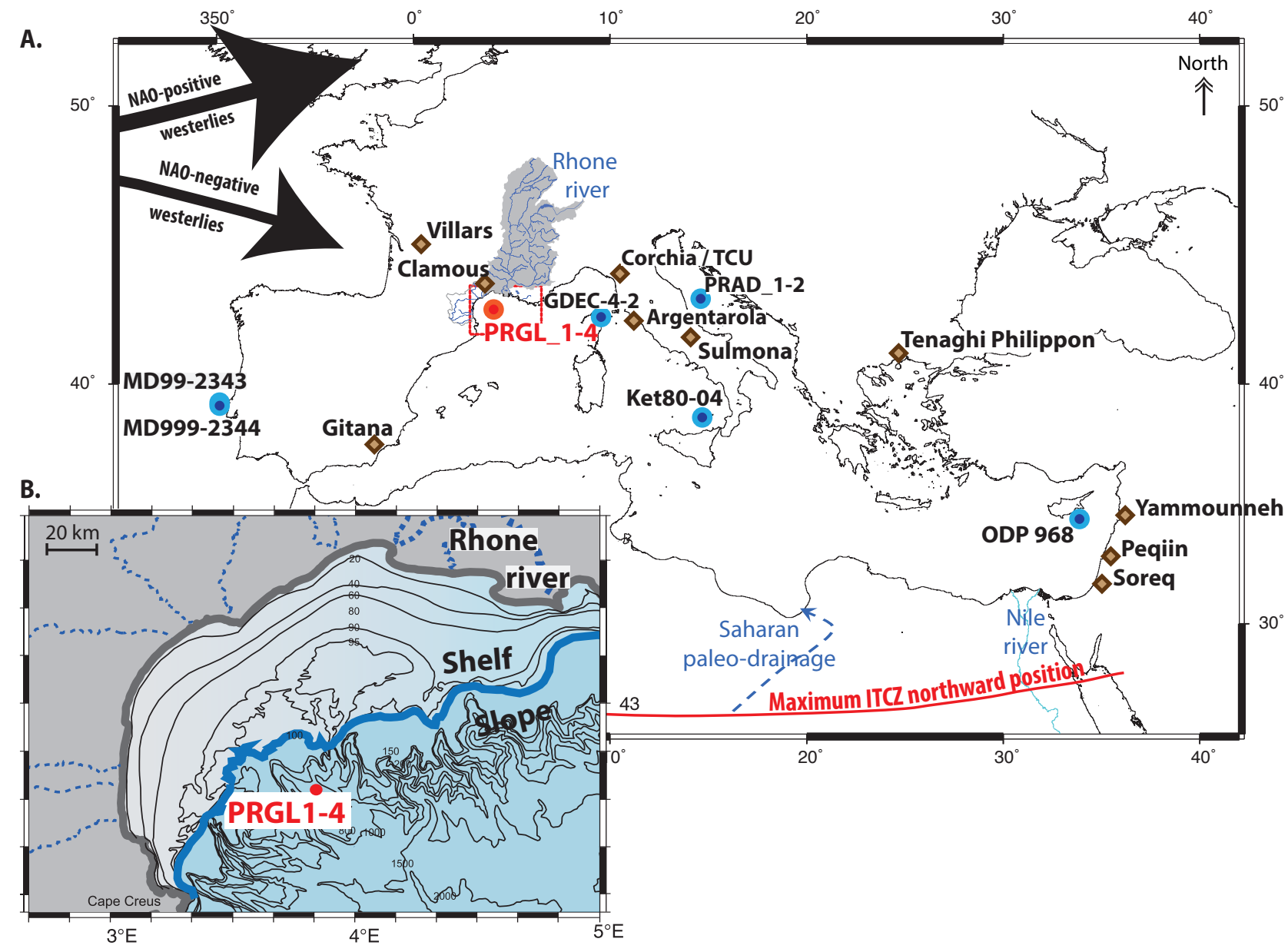

Figure 1 (A). Location of the main sites mentioned in the text, including our study site PRGL1-4 (red circle) and Rhone river catchment area (blue line and grey area). Brown and blue circles (with associated names) represent continental and marine records. The red line over North Africa show the maximum northward displacement of the ITCZ over the last millions years from Tuenter et al. (2003). Course of the Central Saharan rivers according to Coulthard et al. (2013). The general trajectory of the atmospheric westerlies is show for NAO-positive and NAO-negative states according to the present day observation.

(B). Gulf of Lion shelf morphology, red circle corresponds to our study site PRGL1-4, blue line corresponds to the LGM coastline position. 


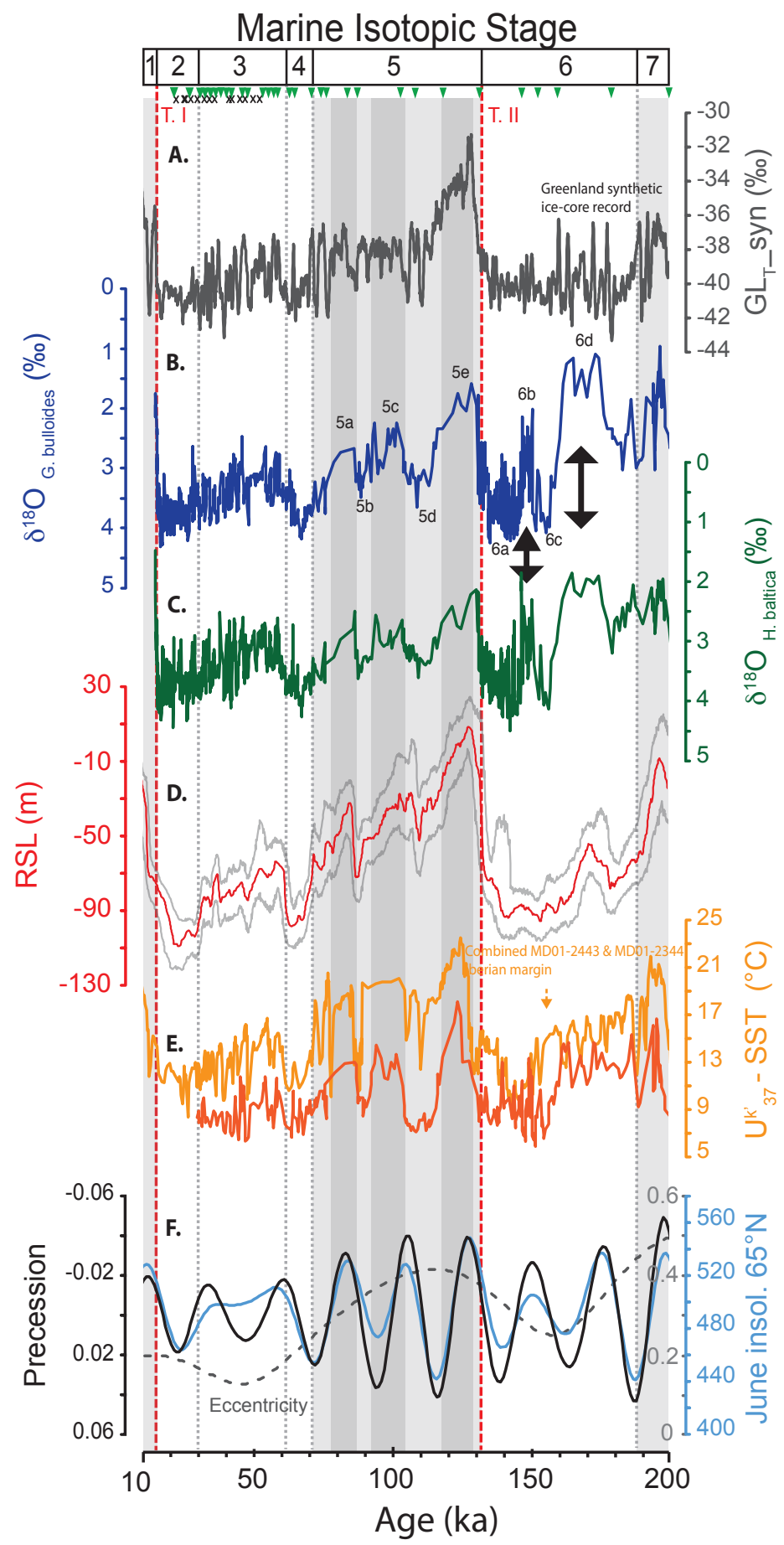

Figure 2: (A) Greenland synthetic $\delta^{18} \mathrm{O}$ record (GLT-syn; Barker et al., 2011); (B) $\delta^{18} \mathrm{O}$ of planktonic species [G. bulloïdes] (Sierro et al., 2009); (C) $\delta^{18} \mathrm{O}$ of benthic species [H. baltica] from PRGL1-4 site (J.F. Sierro unpublished data); (D) Red Sea sea level record (coreKL09, red curve, grey line corresponds to maximum probability 95\%; Grant et al., 2014); (E) $\mathrm{U}_{37}^{\mathrm{k}^{\prime}}$-SST of combined record of core MD01-2444 and MD01-2443 (Iberian margin) yellow line (Martrat et al., 2007) and C37alkenones-SST from PRGL1-4 orange line (Cortina et al., 2015); (F) June insolation for $65^{\circ} \mathrm{N}$ (blue line) with precession (black line) and eccentricity of Earth's orbit (dashed grey line; Laskar et al., 2004). Black arrows highlight unexpected lower $\delta^{18} \mathrm{O}$ during MIS6 warm substages; Top black crosses indicate $\mathrm{C}^{14}$ dating and green triangles indicate position of tie-points (see table1). Grey bands indicate interglacial conditions s.l, dark grey bands indicate interglacial warm-periods.

Termination (T.) according to Barker et al. (2011). Scheme of marine stage according to Railsback et al. (2015). 


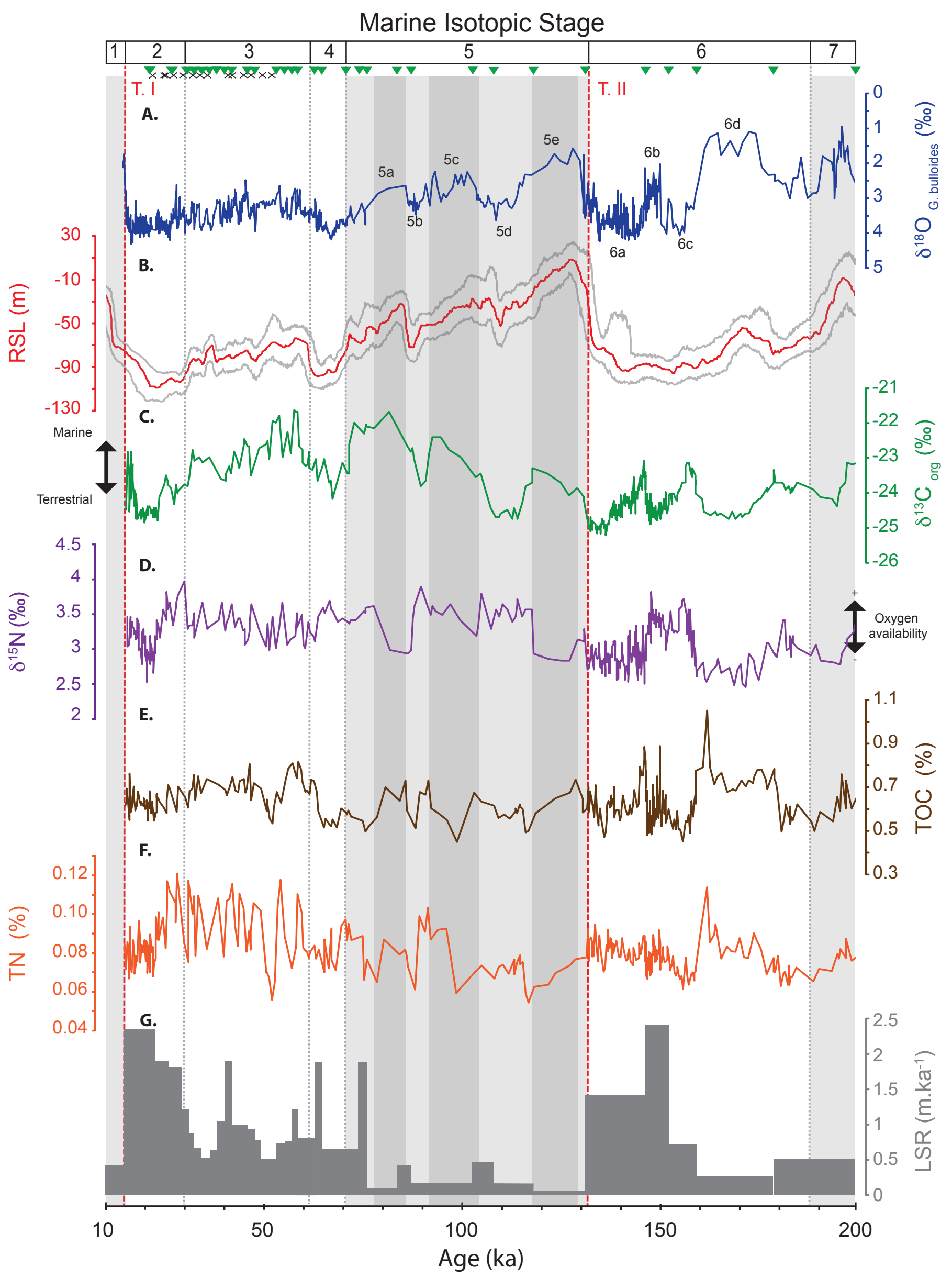

Figure 3: (A) $\delta^{18} \mathrm{O}$ of planktonic species [G. bulloïdes] from PRGL1-4 (Sierro et al., 2009);

(B) Red Sea sea level record (core KL09, red curve, grey line corresponds to maximum probability $95 \%$,

Grant et al., 2014); (C) $\delta^{13} C_{\text {org }}$ of PRGL1-4, this study; (D) $\delta^{15} \mathrm{~N}_{\text {tot }}$ of PRGL1-4, this study; (E) \% of Total Organic Carbon (TOC), this study; (F) \% Total Nitrogen (TN); (G) Linear sedimentation rates (LSR in m.ka ${ }^{-1}$. Top black crosses indicate $\mathrm{C}^{14}$ dating and green triangles indicate position of tie-points (see table1). Grey bands indicate interglacial conditions s.l, dark grey bands indicate interglacial warm-periods. Termination (T.) according to Barker et al. (2011). Scheme of marine stage according to Railsback et al. (2015). 


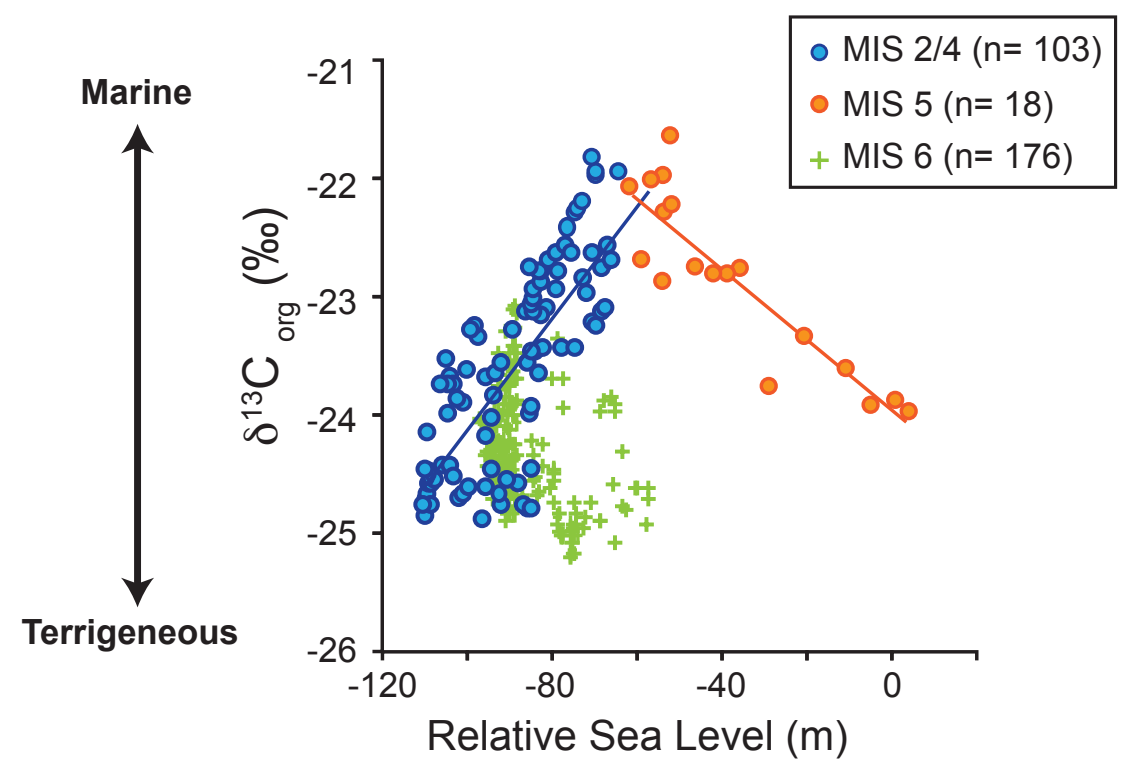

Figure 4: $\delta^{13} C_{\text {org }}$ versus Relative Sea Level reconstruction in Red Sea (Grant et al., 2014).

Blue circles correspond to MIS2/4 values $(n=103)$, orange circles to warm substages of MIS5 $(n=18)$ and green crosses to MIS6 $(n=176)$. 


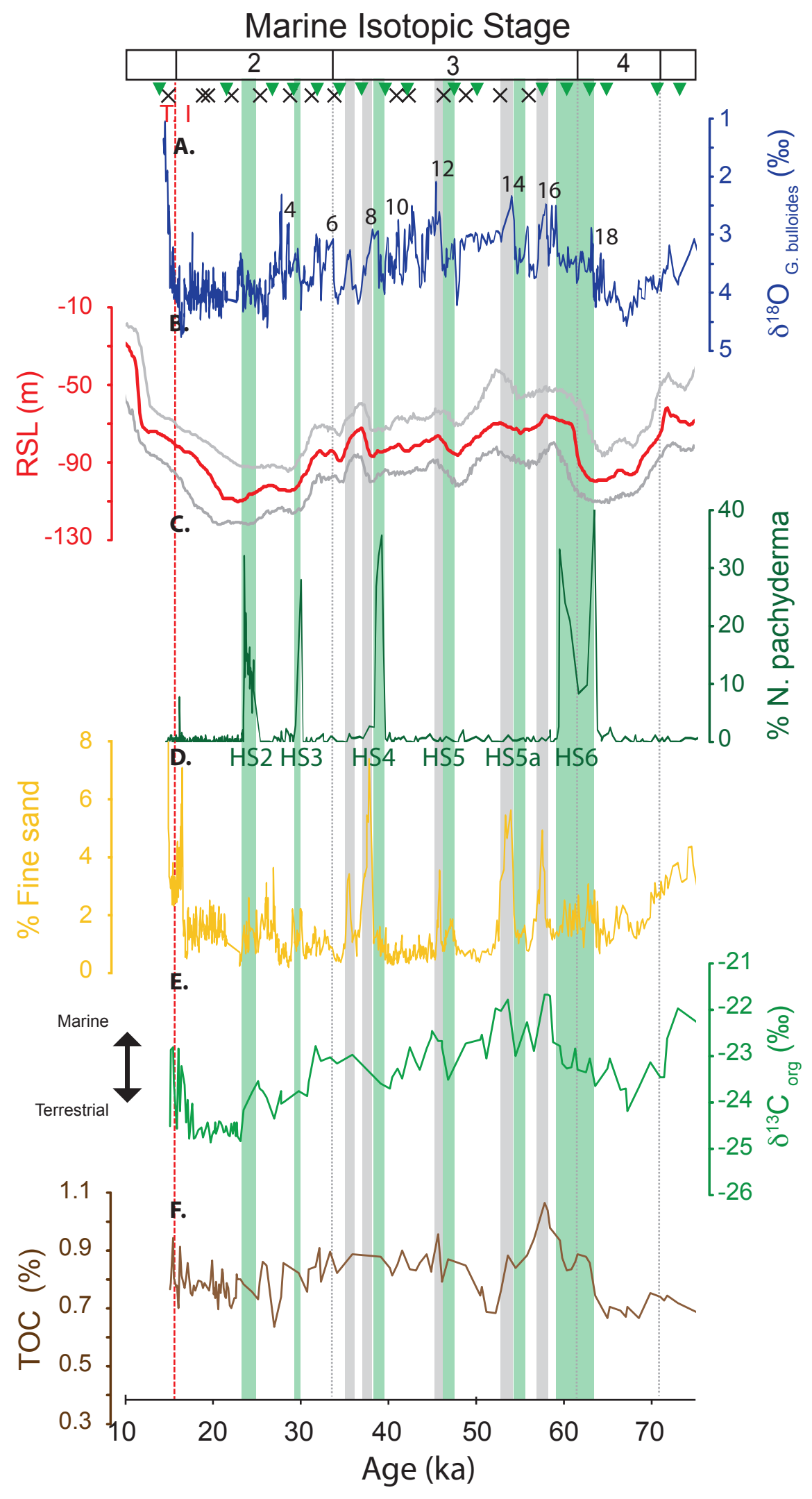

Figure 5: (A) $\delta^{18} \mathrm{O}$ of planktonic species [G. bulloïdes] from PRGL1-4 (Sierro et al., 2009);

(B) Red Sea sea level record (core KL09, red curve, grey line corresponds to maximum probability 95\%, Grant et al., 2014); (C)Percentage of the polar species Neogloboquadrina pachyderma (Sierro et al., 2009);

(D) Percentage of fine sand (Sierro et al., 2009); (E) $\delta^{13} C_{\text {org }}$ of PRGL1-4, this study;

(E) \% of Total Organic Carbon (TOC), this study. Top black crosses indicate $\mathrm{C}^{14}$ dating and green triangles indicate position of tie-points (see table1). Grey bands indicate timing of millenial sea-level flooding events (Sierro et al., 2009). Green bands show timing of Heinrich stadials (Sierro et al., 2009). Termination (T.) according to Barker et al. (2011). Scheme of marine stage according to Railsback et al. (2015). 
Marine Isotopic Stage

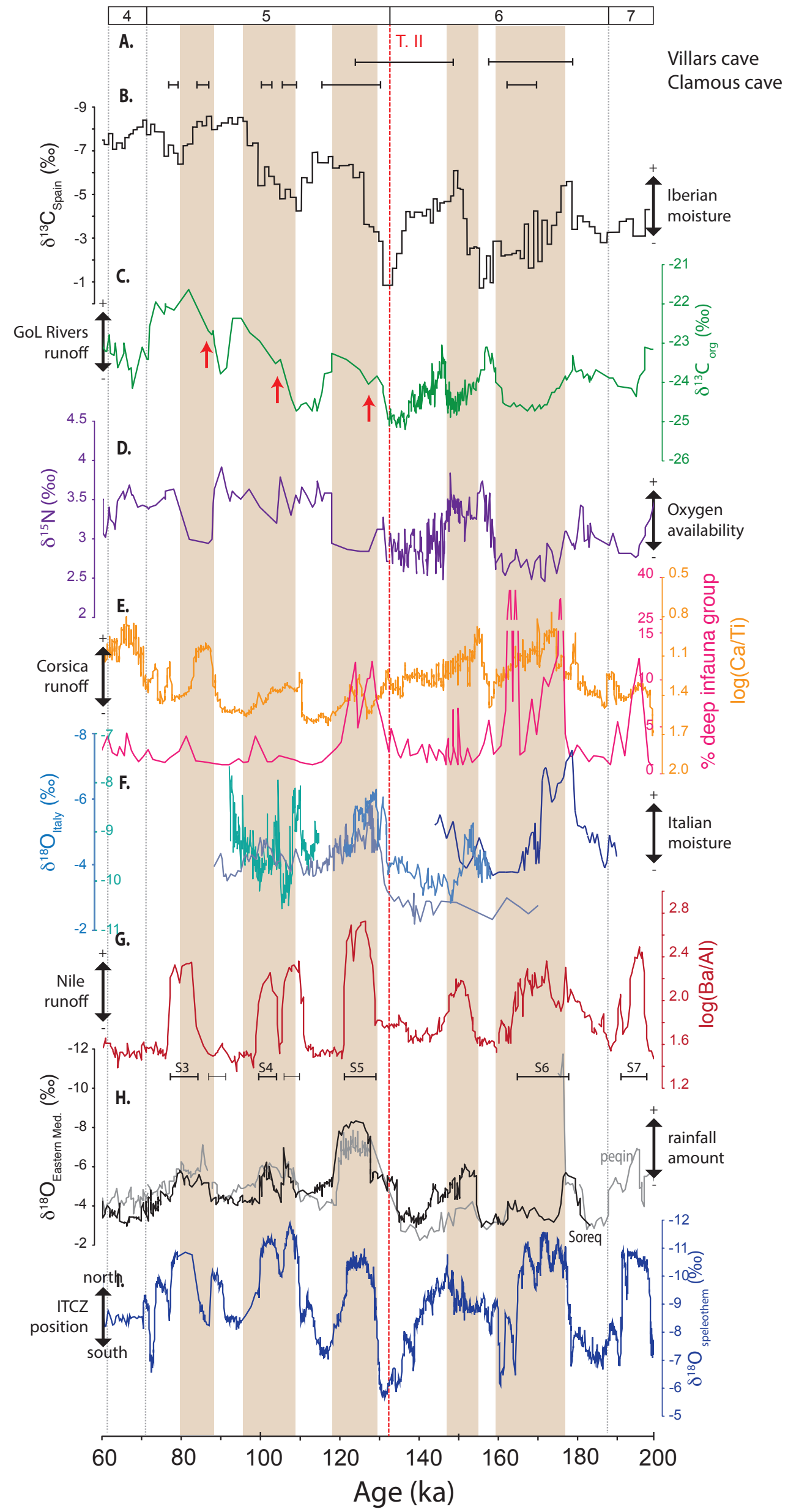

Figure 6: (A) Chronology of speleothem growth periods from Villars and Clamouse caves indicating humid period in South France (respectively Plagnes et al., 2002; Wainer et al., 2011); (B) $\delta^{13} \mathrm{C}$ record at Gitana cave (Spain; Hodge et al., 2008); (C) $\delta^{13} \mathrm{C}$ of PRGL1-4, this study, Red arrows show the gradual increase of precipitation during MIS5 warm susbstages.; (D) $\delta^{15} \mathrm{~N}$ of PRGL1-4, this study; (E) Abundance of benthic foraminifera deep-infaunal group (pink line) and XRF Ti/Ca from Corsica borehole GDEC4 (orange line in log scale, (Toucanne et al., 2015); (F) $\delta^{18} \mathrm{O}$ record from Tana Che urla (centrale Italy, light blue line; Regattieri et al., 2014), Argentarola (Tyrrhenian cost of Italy, dark blue line, Bard et al., 2002), Antro del Corchia (central Italy, blue purple curve, Drysdale et al., 2005), Sulmona basin (aqua curve, Regattieri et al., 2015); (G) XRF Ba/Al (log scale, ODP968 - south Cyprus; Ziegler et al., 2010) and sapropel chronology (speleothem age-scale) according to Ziegler et al. (2010); (H) $\delta^{18} \mathrm{O}$ record of Soreq (Central Israel, black line; Bar-Matthews et al., 2003), Pepiin (north Israel; grey line Bar-Matthews et al., 2003); (I) $\delta^{18} \mathrm{O}$ from Sanbao - Hulu cave (Asia; Wang et al., 2008). Brown bands indicate pluvial periods. Termination (T.) according to Barker et al. (2011). Scheme of marine stage according to Railsback et al. (2015). 


\begin{tabular}{|c|c|c|}
\hline Statigraphic event & $\begin{array}{l}\text { GLT-syn age } \\
\text { (ka BP) }\end{array}$ & $\begin{array}{l}\text { PRGL 1-4 } \\
\text { depth (mbsf) }\end{array}$ \\
\hline Top PRGL 1-4 & 14.2 & 0.00 \\
\hline Onset GI-1 / T.I & 14.8 & 0.25 \\
\hline Onset GI-2 & 23.2 & 19.80 \\
\hline Onset Gl-3 & 27.7 & 27.99 \\
\hline Onset GI-4 & 28.6 & 29.60 \\
\hline End GI-4 & 31.5 & 33.00 \\
\hline Onset GI-5 & 32.1 & 33.55 \\
\hline Onset GI-6 & 33.6 & 34.32 \\
\hline Onset GI-7 & 35.7 & 35.69 \\
\hline Onset GI-8 & 38.8 & 37.00 \\
\hline Onset GI-9 & 40.1 & 38.30 \\
\hline Onset GI-10 & 41.1 & 40.08 \\
\hline Onset GI-11 & 43.0 & 41.96 \\
\hline Onset GI-12 & 46.1 & 44.79 \\
\hline Onset GI-13 & 48.4 & 46.66 \\
\hline Onset GI-14 & 54.1 & 49.44 \\
\hline Onset GI-15 & 55.9 & 50.71 \\
\hline Onset GI-16 & 58.0 & 52.24 \\
\hline Onset GI-17 & 59.1 & 53.59 \\
\hline End Gl-18 & 63.0 & 56.63 \\
\hline Onset GI-18 & 64.2 & 58.95 \\
\hline Onset GI-19 & 72.0 & 63.83 \\
\hline Onset GI-20 & 75.7 & 64.39 \\
\hline End GI-20 & 75.9 & 65.13 \\
\hline Onset GI-21 / MIS 5.1 & 86.5 & 65.52 \\
\hline MIS 5.3 / MIS 5.2 & 89.8 & 66.80 \\
\hline Onset Gi-22 & 103.7 & 68.70 \\
\hline Onset MIS 5.3 / GI-23 & 106.9 & 70.20 \\
\hline Onset MIS 5.4 & 116.3 & 71.60 \\
\hline Onset MIS 5.5 / T.II & 131.0 & 72.40 \\
\hline MIS 6.3 / MIS 6.2 & 146.5 & 93.80 \\
\hline Onset MIS 6.3 & 151.0 & 104.45 \\
\hline Onset MIS 6.4 & 160.0 & 110.80 \\
\hline Onset MIS 6.5 & 178.0 & 115.27 \\
\hline Onset MIS 7.1 & 199.0 & 125.18 \\
\hline Onset MIS 7.2 & 201.2 & 125.46 \\
\hline
\end{tabular}

Table 1: Chronological framework for PRGL 1-4. Age of isotopes events from the synthetic ice Greenland (GLT- ${ }_{\text {syn }}$ ) record of Barker et al. (2011). GI refer to Greenland Interstadial, MIS is Marine Isotope Stage and T correspond to Termination. Scheme of marine stage according to Railsback et al. (2015). 

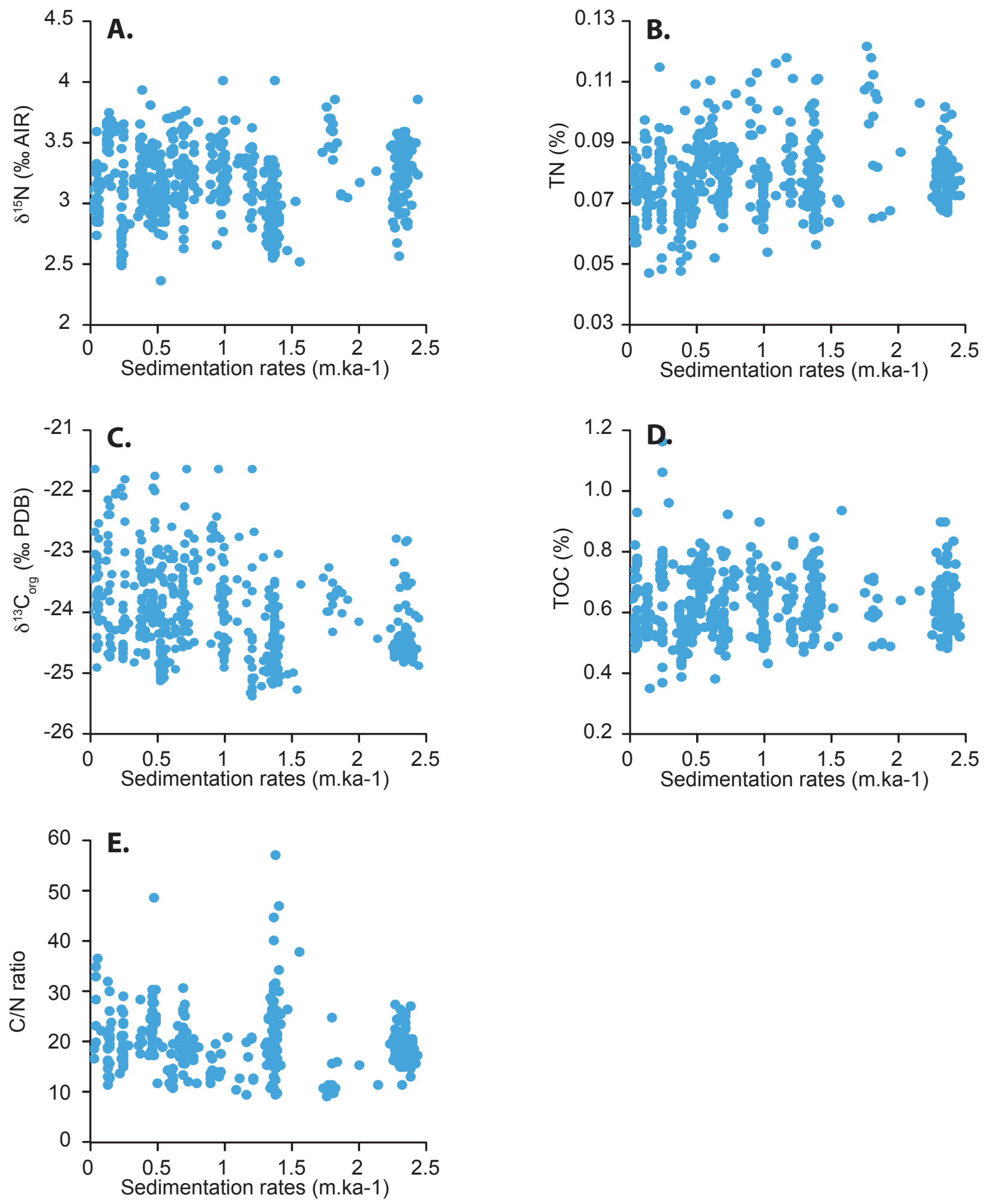

Supplementary Figure 1: (A) $\delta^{15} \mathrm{~N}_{\text {tot }}$ versus linear sedimentation rate; (B) \% of Nitrogen (TN) versus linear sedimentation rate; (C) $\delta^{13} C_{\text {org }}$ versus linear sedimentation rate; (D) \% of Total Organic Carbon (TOC) versus linear sedimentation rate; $(\mathrm{E}) \mathrm{C} / \mathrm{N}$ ratio versus linear sedimentation rate.

Supplementary Figure 1: (A) $\delta^{15} \mathrm{~N}_{\text {tot }}$ versus linear sedimentation rate; (B) $\delta^{15} \mathrm{~N}_{\text {tot }}$ versus $\%$ fine sand (Sierro et al., 2009); (C) \% of Nitrogen (TN) versus linear sedimentation rate; (D) \% of Nitrogen (TN) versus \% fine sand (Sierro et al., 2009); (E) $\delta^{13} C_{\text {org }}$ versus linear sedimentation rate; (F) $\delta^{13} C_{\text {org }}$ versus \% fine sand (Sierro et al., 2009); (G) \% of Total Organic Carbon (TOC) versus linear sedimentation rate; $(\mathrm{H}) \%$ of Total Organic Carbon (TOC) versus \% fine sand (Sierro et al., 2009); 

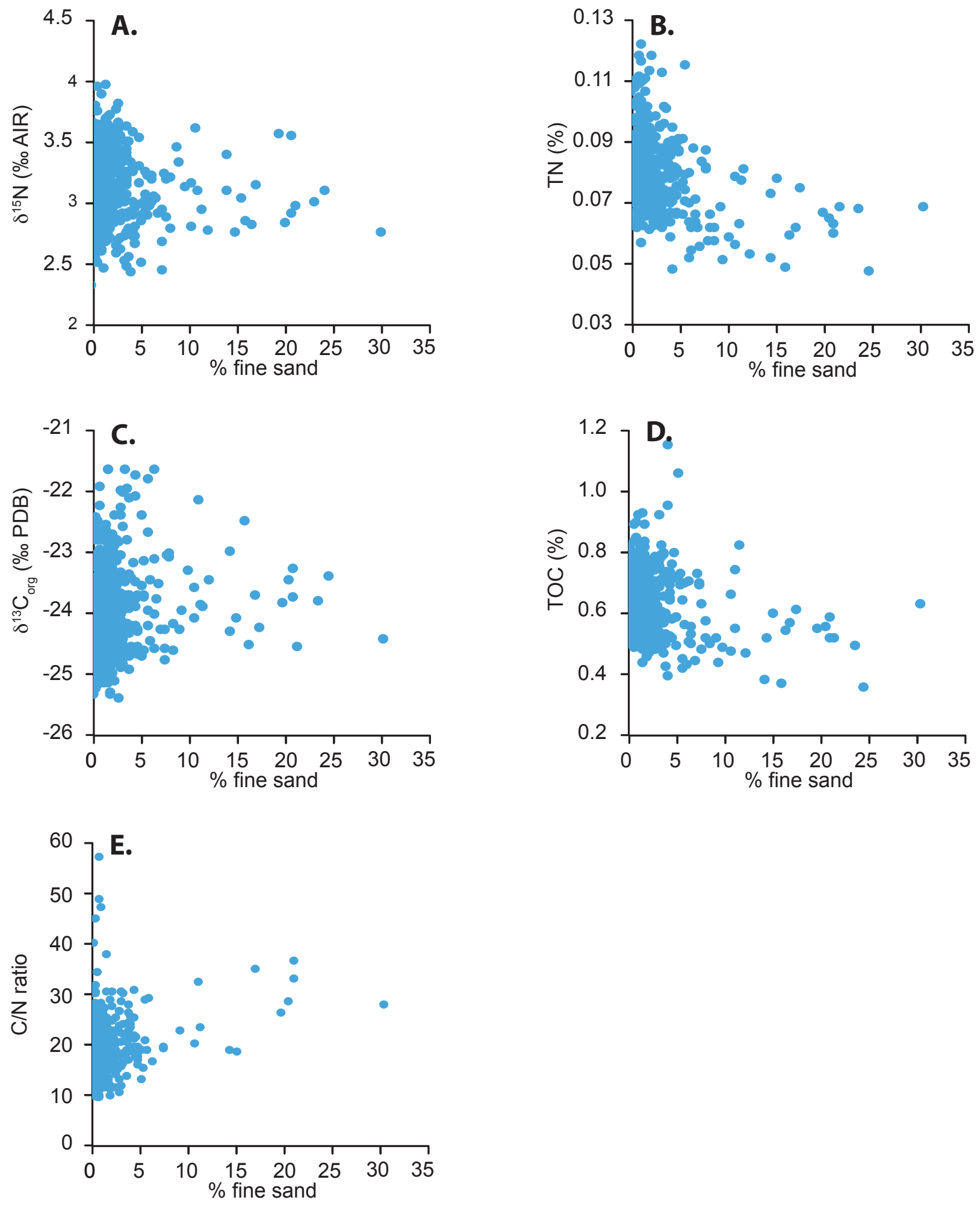

Supplementary Figure 2: (A) $\delta^{15} \mathrm{~N}_{\text {tot }}$ versus \% fine sand (Sierro et al., 2009); (B) \% of Nitrogen (TN) versus \% fine sand (Sierro et al., 2009); (C) $\delta^{13} C_{\text {org }}$ versus \% fine sand (Sierro et al., 2009); (D) \% of Total Organic Carbon (TOC) versus $\%$ fine sand (Sierro et al., 2009); (E) C/N ratio versus \% fine sand (Sierro et al., 2009). 

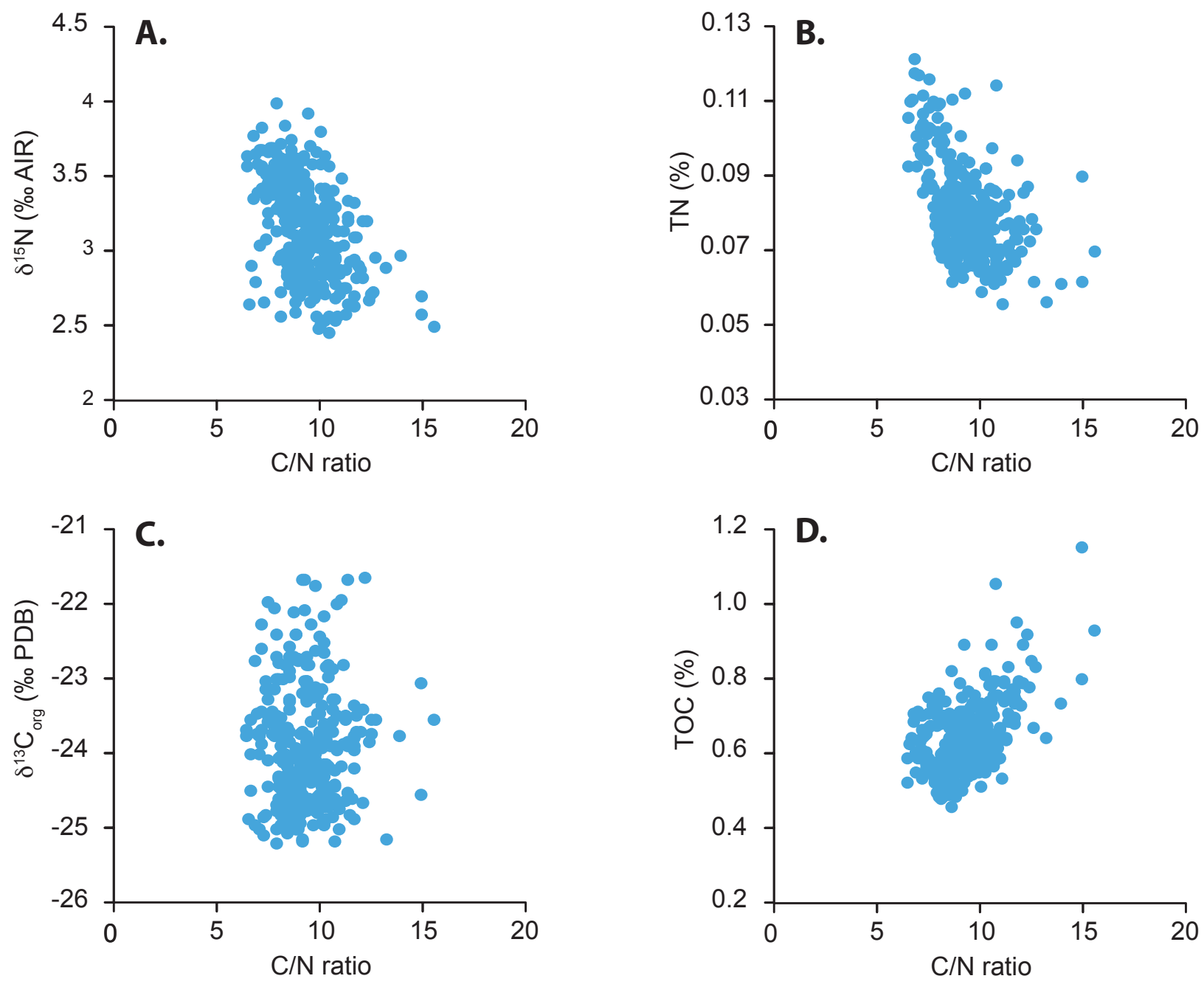

Supplementary Figure 3: (A) $\delta^{15} \mathrm{~N}_{\text {tot }}$ versus C/N ratio; (B) \% of Nitrogen (TN) versus $\mathrm{C} / \mathrm{N}$ ratio; (C) $\delta^{13} C_{\text {org }}$ versus $\mathrm{C} / \mathrm{N}$ ratio; (D) \% of Total Organic Carbon (TOC) versus $\mathrm{C} / \mathrm{N}$ ratio. 